\title{
Petrography and Correlation of Precambrian Clastic Sedimentary Rocks Associated with the Midcontinent Rift System
}

\section{U.S. GEOLOGICAL SURVEY BULLETIN 1989-E}

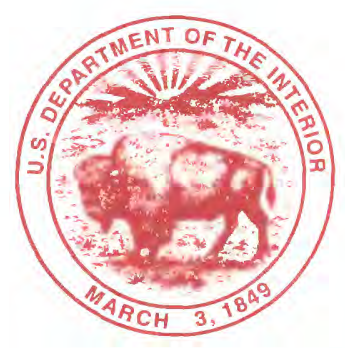




\section{AVAILABILITY OF BOOKS AND MAPS OF THE U.S. GEOLOGICAL SURVEY}

Instructions on ordering publications of the U.S. Geological Survey, along with prices of the last offerings, are given in the current-year issues of the monthly catalog "New Publications of the U.S. Geological Survey." Prices of available U.S. Geological Survey publications released prior to the current year are listed in the most recent annual "Price and Availability List." Publications that may be listed in various U.S. Geological Survey catalogs (see back inside cover) but not listed in the most recent annual "Price and Availability List" may no longer be available.

Reports released through the NTIS may be obtained by writing to the National Technical Information Service, U.S. Department of Commerce, Springfield, VA 22161; please include NTIS report number with inquiry.

Order U.S. Geological Survey publications by mail or over the counter from the offices listed below.

\section{BY MAIL}

\section{Books}

Professional Papers, Bulletins, Water-Supply Papers, Techniques of Water-Resources Investigations, Circulars, publications of general interest (such as leaflets, pamphlets, booklets), single copies of Earthquakes \& Volcanoes, Preliminary Determination of Epicenters, and some miscellaneous reports, including some of the foregoing series that have gone out of print at the Superintendent of Documents, are obtainable by mail from

\section{U.S. Geological Survey, Map Distribution Box 25286, MS 306, Federal Center Denver, CO 80225}

Subscriptions to periodicals (Earthquakes \& Volcanoes and Preliminary Determination of Epicenters) can be obtained ONLY from the

\section{Superintendent of Documents \\ Government Printing Office \\ Washington, DC 20402}

(Check or money order must be payable to Superintendent of Documents.)

\section{Maps}

For maps, address mail orders to

\section{U. S. Geological Survey, Map Distribution Box 25286, Bldg. 810, Federal Center Denver, CO 80225}

Residents of Alaska may order maps from

$$
\begin{aligned}
& \text { U.S. Geological Survey, Earth Science Information Center } \\
& 101 \text { Twelfth Ave., Box } 12 \\
& \text { Fairbanks, AK } 99701
\end{aligned}
$$

\section{OVER THE COUNTER}

\section{Books and Maps}

Books and maps of the U.S. Geological Survey are available over the counter at the following U.S. Geological Survey offices, all of which are authorized agents of the Superintendent of Documents.

- ANCHORAGE, Alaska-Rm. 101, 4230 University Dr.

- LAKEWOOD, Colorado-Federal Center, Bldg. 810

- MENLO PARK, California-Bldg. 3, Rm. 3128, 345 Middlefield Rd.

- RESTON, Virginia-USGS National Center, Rm. 1C402, 12201 Sunrise Valley Dr.

- SALT LAKE CITY, Utah-Federal Bldg., Rm. 8105, 125 South State St.

- SPOKANE, Washington-U.S. Post Office Bldg., Rm. 135, West 904 Riverside Ave.

- WASHINGTON, D.C.-Main Interior Bldg., Rm. 2650, 18th and C Sts., NW.

\section{Maps Only}

Maps may be purchased over the counter at the following U.S. Geological Survey offices:

- FAIRBANKS, Alaska-New Federal BIdg, 101 Twelfth Ave.

- ROLLA, Missouri-1400 Independence Rd.

- STENNIS SPACE CENTER, Mississippi-Bldg. 3101 
Chapter E

Petrography and Correlation of Precambrian Clastic Sedimentary Rocks Associated with the Midcontinent Rift System

By PIETER BERENDSEN and ANDRZEJ BARCZUK

STRATEGIC AND CRITICAL MINERALS IN THE MIDCONTINENT REGION, UNITED STATES 


\title{
U.S. DEPARTMENT OF THE INTERIOR \\ BRUCE BABBITT, Secretary
}

\author{
U.S. GEOLOGICAL SURVEY
}

Dallas L. Peck, Director

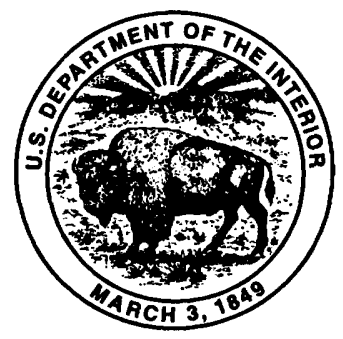

Published in the Central Region, Denver, Colo.

Manuscript approved for publication April 21, 1993.

Photocomposition by Marie Melone

Any use of trade, product, or firm names in this publication is for descriptive purposes only and does not imply endorsement by the U. S. Government

UNITED STATES GOVERNMENT PRINTING OFFICE: 1993

For sale by

USGS Map Distribution

Box 25286, Building 810

Denver Federal Center

Denver, CO 80225

\section{Library of Congress Cataloging-in-Publication Data}

Berendsen, Pieter.

Petrography and correlation of Precambrian clastic sedimentary rocks associated with the Midcontinent Rift System / by Pieter Berendsen and Andrzej Barczuk.

p. cm.-(U.S. Geological Survey bulletin ; 1989)

(Strategic and critical minerals in the midcontinent region, United States ; ch. E) Includes bibliographical references.

Supt. of Docs. no.: I 19.3: 1989E

1. Geology, Stratigraphic-Precambrian. 2. Rocks, Sedimentary-Middle

West. 3. Petrology - Middle West. 4. Stratigraphic correlation-Middle West.

5. Keweenawan Rift. I. Barczuk, Andrzej. II. Title. III. Series. IV. Series: Strategic and critical minerals in the midcontinent region, United States : ch. E.

QE75.B9 no. 1989-E

[QE653]

$557.3 \mathrm{~s}$-dc20

[551.7'1'0977] 


\section{CONTENTS}

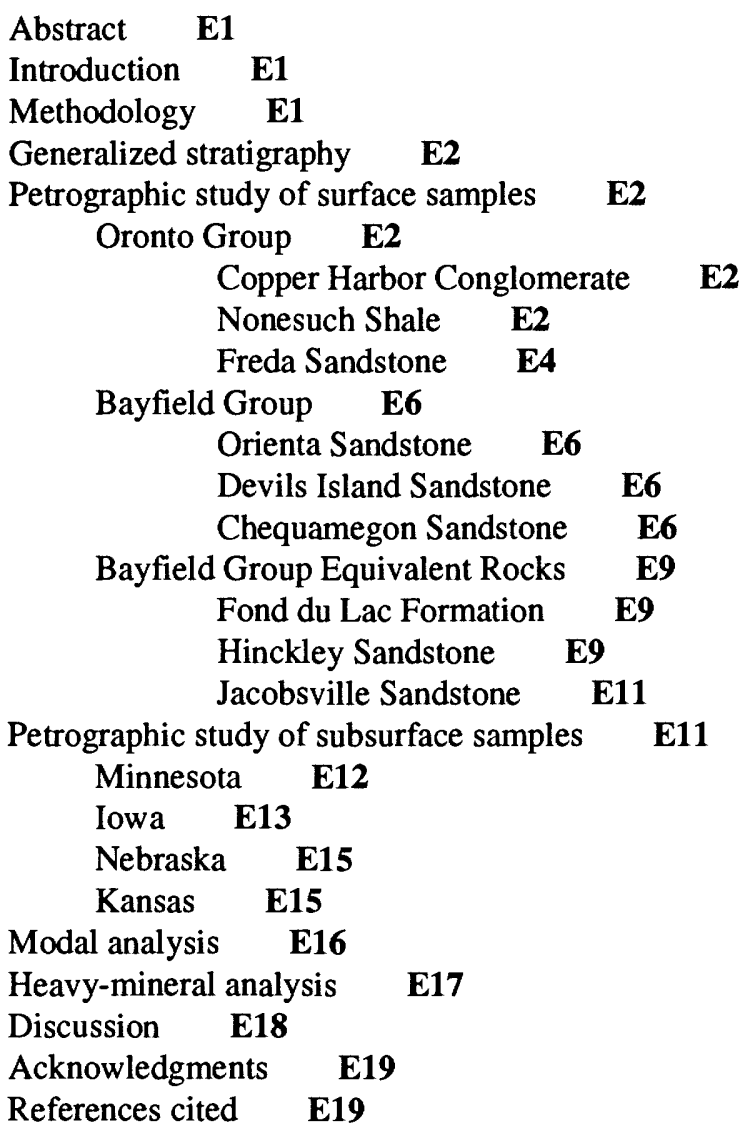

\section{FIGURES}

E1. Chart showing stratigraphic terminology and correlations of upper Keweenawan clastic rocks $\quad \mathbf{E 3}$

E2. Generalized geologic map of the western Lake Superior region showing the distribution of and sample localities for Keweenawan surface rocks $\quad$ E3

E3. Triangular diagram showing petrographic composition of Precambrian sedimentary rocks of the northern part of the Midcontinent Rift System $\quad$ E8

E4. Triangular diagram showing petrographic composition of Precambrian sedimentary rocks of the northern part of the Midcontinent Rift System based on the composition of their constituent rock fragments E10

E5. Generalized geologic map showing the subsurface distribution of Keweenawan rocks in southern Minnesota, Iowa, and eastern Nebraska, and the location of drill holes discussed in text E11

E6. Map showing generalized distribution of Keweenawan-age rocks in Kansas and approximate location of drill holes from which samples were taken $\quad$ E12

E7. Chart showing preliminary stratigraphic correlation of drill-hole cuttings from Kansas with established stratigraphy in the northern part of the Midcontinent Rift System E16 


\section{TABLES}

E1. Petrographic composition of volcaniclastic and clastic sedimentary rocks associated with the Midcontinent Rift System

E5

E2. Heavy-mineral composition of volcaniclastic and clastic sedimentary rocks associated with the Midcontinent Rift System

E7

E3. Heavy-mineral composition of core and cuttings from drill holes in Minnesota, Iowa, and Kansas E14 


\title{
Petrography and Correlation of Precambrian Clastic Sedimentary Rocks Associated with the Midcontinent Rift System
}

\author{
By Pieter Berendsen ${ }^{1}$ and Andrzej Barczuk ${ }^{2}$
}

\begin{abstract}
Rocks from exposures in the Lake Superior region and from core and cuttings of exploration drill holes in Iowa, Nebraska, and Kansas were analyzed to correlate the subsurface clastic sedimentary rocks in the southern extension of the Midcontinent Rift System with rocks of the established Keweenawan stratigraphy in the Lake Superior region. Petrographic properties and heavy minerals were used to characterize the various formations. Rocks similar in character to those of the Oronto Group and the Bayfield Group are recognized in the subsurface in Iowa, Nebraska, and Kansas. For comparative purposes, additional analyses were made on surface samples collected throughout the Lake Superior region.
\end{abstract}

\section{INTRODUCTION}

During the past five years cooperative studies by the Kansas Geological Survey and the U.S. Geological Survey (USGS) as part of the USGS Midcontinent Strategic and Critical Minerals Project (MSCM) have significantly contributed to our understanding of the stratigraphy and structure of the Precambrian rocks associated with the Midcontinent Rift System, especially in that part of the rift where Phanerozoic rocks overlie the Precambrian. The approximately $1,000-\mathrm{mi}(1,500-\mathrm{km})$-long arm of the Midcontinent Rift System, stretching from the northern end of Lake Superior southwestward into south-central Kansas, can be divided into three segments that are left-laterally 66047.

${ }^{1}$ Kansas Geological Survey, University of Kansas, Lawrence, KS

${ }^{2}$ Department of Geology, University of Warsaw, Warsaw, Poland. offset with respect to each other. The initial extensional phase of rifting, beginning about $1,100 \mathrm{Ma}$, was accompanied by emplacement of sizable mafic intrusive bodies and subsequent voluminous outpouring of mafic volcanic rock. In the ensuing stages of rift development, initially coarse and immature sediments, followed by increasingly finer and more mature sediments, collected in the basins that developed along the trend of the rift. The coarser sediments contained a large percentage of debris derived from mafic volcanic rocks in the center of the rift, and the younger, predominantly fluviatile sediments were dominated by material from the rift shoulders.

This study contributes information on the petrology and mineralogy of subsurface Precambrian sedimentary rocks encountered in drill holes in Minnesota, Iowa, Nebraska, and Kansas. New data from surface samples collected as part of this study, together with published information on volcaniclastic and clastic rocks in the outcrop area, allow for a comparison and initial correlation between the subsurface stratigraphy of the rift and the exposed stratigraphic sequence in the Great Lakes region.

\section{METHODOLOGY}

During the first phase of this MSCM project 23 outcrops of the major post-volcanic clastic sedimentary rocks in Minnesota, Wisconsin, and Michigan were examined, sampled, and described with the aid of a binocular microscope (R.R. Anderson, Iowa Geological Survey; R.M. McKay; P.Berendsen; A. Barczuk; G.B. Morey; P. McSwiggin; and M.P. Carlson, written commun., 1987). In addition, representative samples of well cuttings were collected from a selected number of drill holes penetrating the pre-Paleozoic sedimentary section in Minnesota, Iowa, 
Nebraska, and Kansas, and the rocks were described. As a result, a total of 130 thin sections were prepared: 65 of rocks from surface exposures, 45 from drill-hole cuttings, and 20 from drill core. Of these, 50 thin sections were point counted and 30 were stained to estimate porosity. Twenty-seven samples were disaggregated, and the heavy minerals were separated in bromoform. The heavymineral separates were in turn point counted. Some samples were analyzed by X-ray diffraction where necessary, especially clay-rich samples.

\section{GENERALIZED STRATIGRAPHY}

The generalized stratigraphic relationships of the rocks associated with the Midcontinent Rift System are shown in figure E1. Recent papers by Dickas (1986), and a number of papers in Wold and Hinze (1982), and references included therein, provide details about the stratigraphy and the difficulties of correlation even within the outcrop belt in the Great Lakes region. The initial opening of the rift at about 1,100 Ma was accompanied by voluminous outpourings of predominantly mafic volcanic rocks. The rift basin was subsequently filled with immature sediments that initially contained large quantities of the nearby volcanic rocks, followed by increasingly more mature sediments. The sediments may be divided into an older volcaniclastic sequence represented by the Oronto Group and Solor Church Formation, and a younger clastic sequence represented by the Bayfield Group, the Fond du Lac Formation, and the Hinckley Sandstone. The "Red Clastic series" (Lugn, 1934) in Nebraska and the Rice Series (Baars, in press) in Kansas collectively include all the post-volcanic undivided sedimentary rocks.

\section{PETROGRAPHIC STUDY OF SURFACE SAMPLES}

\section{Oronto Group}

Oronto Group rocks, made up of three petrologically distinct formations interpreted to have been deposited soon after cessation of rift volcanism, are exposed from north-central Wisconsin northeastward throughout the Keweenaw Peninsula in Michigan, and on Isle Royale in Lake Superior.

\section{Copper Harbor Conglomerate}

The Copper Harbor Conglomerate (Daniels, 1982) is a distinct rock type easily recognized by its mineralogical immaturity, high content of various kinds of volcanic rock fragments, high content of altered microcline, lack of micas, and the occurrence of zeolites.
This formation is as thick as $6,900 \mathrm{ft}(2,100 \mathrm{~m})$; it thickens and fines to the northwest towards the axis of the rift (Daniels, 1982). It also fines upward into a mediumto coarse-grained volcanic sandstone (Daniels, 1982). A clast-supported conglomerate facies is common in the lower part of the formation, indicating deposition in a prograding alluvial-fan complex. The environment of deposition changed upward into a shallow-water fluvial regime in which the volcanic sandstone was deposited.

Two sites on the north shore of the Keweenaw Peninsula were examined, both areas that typify the Copper Harbor Conglomerate (fig. E2): one near Eagle River (locality 18, fig. E2) and the other at Copper Harbor (locality 19 , fig. E2), Mich. The rocks there are very coarse grained, conglomeratic volcanic sandstone (samples 18a and $18 \mathrm{~b}$ ) and very coarse grained, sandy volcanic conglomerate (sample 19). The sandy cement in sample 18a is composed of calcite ( 9.4 percent), iron minerals ( 2.8 percent), aleuritic quartz ( 2.0 percent), and zeolites ( 2.0 percent; table 1). Sample 19 has a similar sandy matrix in which iron minerals ( 25.6 percent) and zeolites ( 7.2 percent) predominate. Quartz, most of it showing abraded secondary overgrowths, makes up from 2.6 to 5.4 percent of the rock by volume. Feldspar (5.7-12.6 percent) consists of slightly to intensely altered microcline and associated minor plagioclase (albite), orthoclase, and perthite. Chlorite and other phyllosilicates are rare.

Volcanic rocks make up most of the rock fragments (43.0-54.6 percent). In samples $18 \mathrm{a}$ and $18 \mathrm{~b}$ altered rhyolite, basalt, and diabase are prominent. In sample 19 trachyte having fluidal texture and containing potassium feldspar fragments predominate; basalt and diabase are minor constituents. Some andesite fragments are present, and sample 19 shows a large clast of lithoclastic tuff that contains voids filled with zeolites. Sedimentary rock fragments ( 2.2 percent) of chert, shale, ferruginous mudstone, and sandstone, and metamorphic fragments of quartzite, various types of schist, quartz ferruginous rock, and cataclasite are the most common. The heavy minerals are mostly opaque, but include small amounts of apatite, zircon, epidote, rutile, and sillimanite (table E2).

\section{Nonesuch Shale}

The Nonesuch Shale underlies the Freda Sandstone and crops out from just south of Ashland, Wis., northeastward to near Calumet on the Keweenaw Peninsula in Michigan, more or less parallel to the Lake Superior shoreline. Shale constitutes only a small part of the formation, the bulk of the rock consisting of siltstone and very fine grained sandstone.

We examined and collected Nonesuch Shale samples at Potato River Falls, near Gurney, Wis. (locality 16, fig. E2), and at Silver City (locality 24, fig. E2) and in Porcupine 


\begin{tabular}{|c|c|c|c|c|}
\hline KANSAS AND NEBRASKA & IOWA AND MINNESOTA & \multicolumn{3}{|c|}{ WISCONSIN AND MICHIGAN } \\
\hline \multirow{6}{*}{$\begin{array}{l}\text { Rice Series (Kansas) } \\
\text { and } \\
\text { red clastics (Nebraska) }\end{array}$} & \multirow[b]{2}{*}{ Hinckley Sandstone } & \multirow{3}{*}{ 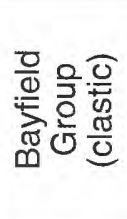 } & Chequamegon Sandstone & \multirow{3}{*}{ 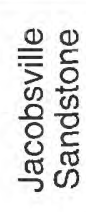 } \\
\hline & & & Devils Island Sandstone & \\
\hline & Fond du Lac Formation & & Orienta Sandstone & \\
\hline & & 응원 & Freda Sandstone & \\
\hline & Solor Church Formation & 일 & Nonesuch Shale & \\
\hline & & & Copper Harbor Conglor & \\
\hline
\end{tabular}

Figure E1. Stratigraphic terminology and correlations of upper Keweenawan clastic rocks.

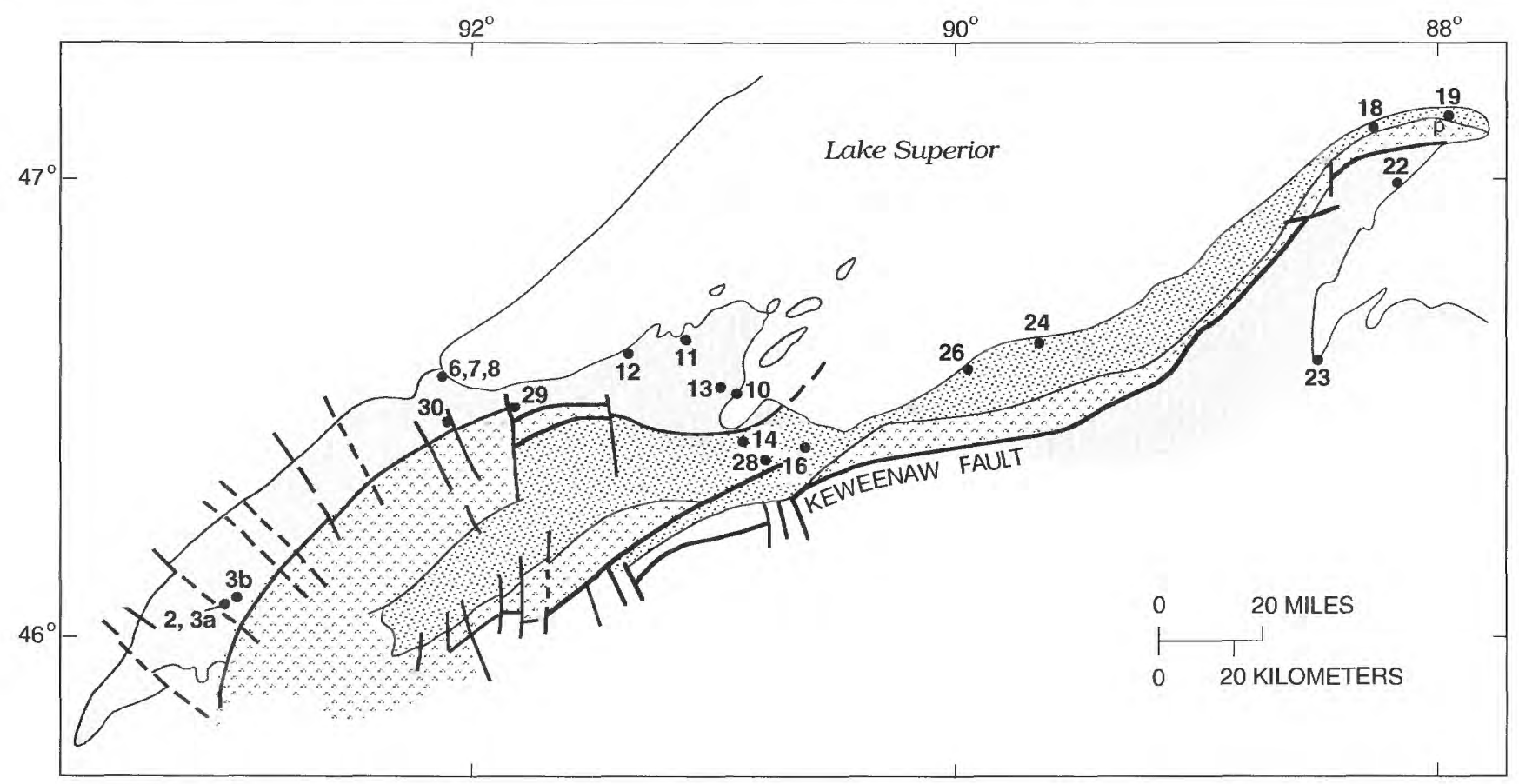

EXPLANATION

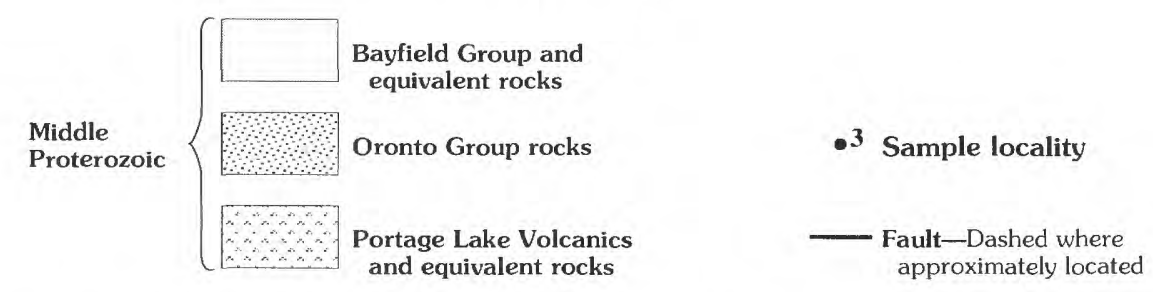

Figure E2. Generalized geologic map of the western Lake Superior region showing the distribution of and sample localities for Keweenawan surface rocks discussed in the text (modified from Morey and Green, 1982). 
State Park at Presque Isle Inlet (locality 26, fig. E2), both in Michigan. The rocks examined are fine- to mediumgrained litharenites (sample 26), medium- to coarse-grained litharenite (sample 16a), fine-grained to very fine grained arkosic arenite (samples $16 \mathrm{~b}$ and $16 \mathrm{c}$ ), laminated clay shale (sample 24), and laminated muddy-ferruginous shale (sample 24a). Cement consists mainly of clay minerals impregnated with varying amounts of iron oxides. Samples from some places (for example, 16a, 16b, and 16c) contain relatively large amounts (15.2-23.2 percent, table E1) of an unusual ferruginous-zeolitic-chloritic cement. The cement in sample $16 \mathrm{c}$ also contains chalcedony. Most of the cement is believed to be of secondary origin, resulting from the alteration of pyroclastic material.

Angular quartz, of pyroclastic origin, has corroded embayments and inclusions of devitrified glass. Secondary overgrowths or other signs of recrystallization are rare. The feldspars are similar to those in the Freda Sandstone, consisting of abundant unaltered microcline and lesser amounts of plagioclase, altered microcline, perthite, and orthoclase.

The shale contains a large amount of deformed phyllosilicates, mostly chlorite (4.3-20.1 percent; table E1). Two types of chlorite are recognized. One is a replacement of detrital biotite, and the other is a metasomatic replacement of volcanic glass. Brown or green, highly altered biotite and muscovite are accessory minerals. Quartz-mica-sericite-graphite-epidote schist, quartzite, quartz-ferruginous rock, and cataclasite are the most prevalent rock fragments. A lesser amount of sedimentary rock fragments consisting of chert, chalcedony, and clayey or clayey-ferruginous shale are present. Mafic volcanic rock fragments (basalt and diabase) are rare. The heavymineral fraction is predominantly opaque minerals and epidote derived from the alteration of plagioclase (table E2).

The Nonesuch Shale is generally conformable with the underlying Copper Harbor Conglomerate, but a transgressive relationship was observed in some areas (Daniels, 1982). Economic concentrations of copper and silver (Ensign and others, 1968) and some liquid hydrocarbon (oil) (Eglinton and others, 1964; Kelly and Nishioka, 1985) occur in the slightly metamorphosed Nonesuch Shale at the underground White Pine copper mine in Michigan. Because of the potential for hydrocarbon accumulations in the shale (Dickas, 1984) in the Great Lakes area and probable lithologically equivalent rocks in the progressively more deeply buried southern extension of the rift, the Nonesuch Shale has received attention in numerous studies and related exploration activities.

Generally, the shale accumulated in a standing body of water (White, 1972; Hubbard, 1975). Regional fluvial influences and local periodic subaerial exposure account for lateral lithological variations. A progressive increase in the maturity of the rocks towards the east, mostly involving a decrease in the amount of mafic fragments and a concomitant increase in the amount of quartz, was noted by several workers and reported by Daniels (1982), who also suggested that the more mature sediments were deposited towards the center of the basin. If this is true, it might suggest a shift in the depocenter over time.

\section{Freda Sandstone}

The characteristic features of the Freda Sandstone are the mineralogical immaturity, the relatively high feldspar content (including plagioclase), the variable provenance of the rock fragments together with a high content of volcanic rock, the low quartz content, and the elevated amount of authigenic epidote.

We examined samples from south of Ashland along the White River (locality 14, fig. E2), at Copper Falls State Park near Mellon (locality 28, fig. E2), Wis., and at Porcupine Mountain State Park, Presque Isle Inlet (locality 26, fig. E2), Mich. The rocks are predominantly reddishbrown, poorly sorted, tuffaceous litharenites containing many semirounded volcanic rock fragments. Sample 28, from Copper Falls State Park, is a tuffite. The average grain size of the litharenites is about $2 \mathrm{~mm}$, but grains as great as $4 \mathrm{~mm}$ are common. The cement is mostly composed of clay minerals impregnated with iron oxides, probably derived from altered volcanic ash. Sample 14c contains as much as 15 percent secondary calcite cement, and sample 28 is recognized by its unusually high content of zeolites in the calcite cement. Quartz, typically of volcanic origin and having a characteristic angularity, corroded embayments, and abundant inclusions of volcanic glass, makes up only a small percentage of the rock (table E1). Feldspar (6.4-17.1 percent), consists mostly of unaltered microcline, perthite, and orthoclase.

In contrast to the younger sandstone units, the Freda Sandstone contains from 0.7 to 3.3 percent secondary albite after primary plagioclase. Volcanic grains account for the bulk of the rock fragments present. Basalt having felsitic and micro-ophitic textures, diabase showing ophitic and in some cases graphic textures, and altered rhyolite are common rock fragments. Trachyte, trachybasalt, tuff, and tuffite are of minor importance. A few grains of serpentinite and metavolcanic diabase, rich in epidote, also are present. Sedimentary rock fragments (5-6.5 percent) consist of ferruginous shale, mudstone, siltstone, and fine-grained micaceous sandstone that commonly shows bedding or parallel laminae. Chert and chalcedony are present locally. Quartzite, quartz-ferruginous rock together with minor quartz-mica sericite schist and cataclasite make up the metamorphic rock fragments (4.4-5.7 percent). Granitoids (1.0-2.1 percent) occur only in the coarser grained sandstones. Opaque minerals and secondary euhedral epidote make up the bulk of the heavy minerals ( $0.7-3.0$ percent). 


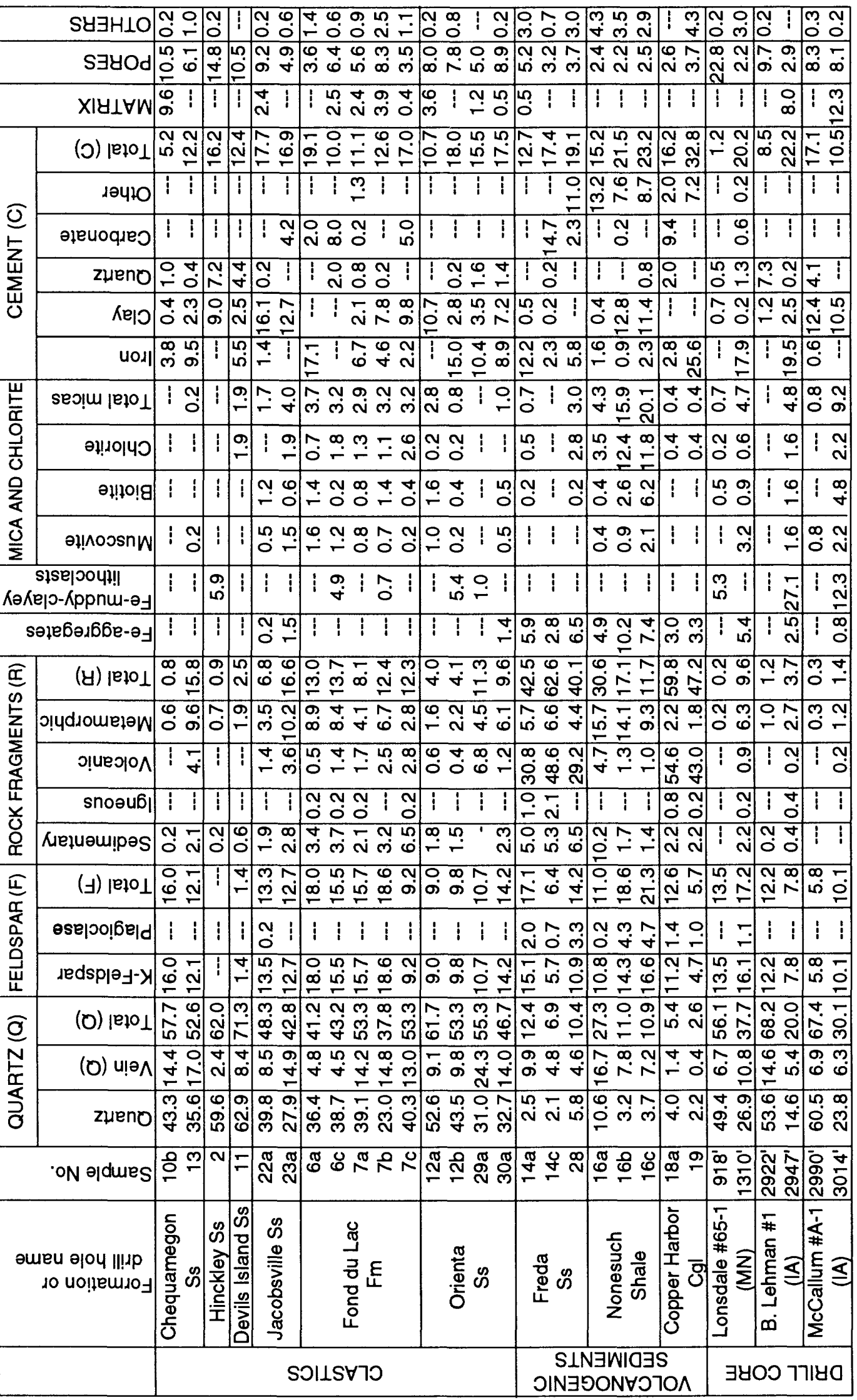


Apatite and pyrochlore are considered to be epigenetic. Detrital garnet, zircon, and rutile are rare (table E2). The composition compares well with results reported by others, including Daniels (1982). A considerable variation in the lateral composition of the sandstone is expected as a result of local variation in sediment sources.

The contact of the Freda Sandstone with the underlying Nonesuch Shale is gradational and marked by an increase in the state of oxidation, grain size, and bedding thickness (Daniels, 1982). The upper contact with rocks of the overlying Jacobsville Sandstone or the Bayfield Group is nowhere exposed. The Freda Sandstone increases in thickness in a southerly direction from about $1,500 \mathrm{ft}(455$ $\mathrm{m}$ ) on the northern Keweenaw Peninsula to about 4,000 $\mathrm{ft}$ $(1,215 \mathrm{~m})$ in Wisconsin. In general, the rocks may be characterized as a fining-upward sequence containing minor conglomeratic units in the lower part of the formation and some siltstone units throughout. A fluvial origin for the deposition of the Freda Sandstone is favored by Daniels (1982), but lacustrine, flood plain, tidal flat, or a combination of these have been proposed by earlier authors (Hamblin, 1961a,b; Noble, 1965; Hite, 1968).

\section{Bayfield Group}

The Bayfield Group consists mainly of fluviatile and minor lacustrine sandstones that are exposed along the Wisconsin shore of Lake Superior. Rocks considered to be of equivalent age in Minnesota and Michigan have been referred to by different names and will be discussed separately.

\section{Orienta Sandstone}

Buff to red feldspathic to arkosic sandstone makes up the bulk of the Orienta Sandstone (Morey and Ojakangas, 1982). The average composition is 85 percent quartz, 11 percent feldspar, and 4 percent labile rock fragments (Myers, 1971). The Orienta Sandstone is mineralogically immature and has a high content of microcline and metamorphic rock fragments. It contains muddy-clayey intraclasts and pyroclastic materials, deformed minerals, and recrystallized quartz.

Samples were collected along the Iron River near Port Wing (locality 12), in Amnicon Falls State Park (locality 29), and in Pattison Falls State Park (locality 30), all in Wisconsin (fig. E2). They show the sandstone to be a fine- to coarse-grained, angular to rounded subarkose and in some places very coarse grained to conglomeratic sublitharenite (fig. E3), similar in composition to that recorded by Morey and Ojakangas (1982). Recrystallized, deformed, and corroded quartz grains make up from 46 to 62 percent of the rock. In the coarser grained rocks the quartz grains are generally well rounded, as opposed to the poorly rounded grains in the finer grained rocks. Some of the quartz grains show signs of a possible pyroclastic origin, such as corroded embayments, increased elongation, and inclusion of devitrified glass. Some quartz grains contain abundant rutile needles. Other quartz grains may have been recycled several times, the grain edges being abraded and recrystallized each time. Feldspar, which makes up from 9 to 14 percent of the rock, is mainly unaltered microcline and minor amounts of altered microcline, perthite, and orthoclase (table E1).

Rock fragments, which make up from 4 to 11 percent of the sandstone, are similar to those found in the Fond du Lac Formation (table E1). Metamorphic rock fragments consisting mainly of quartzite, cataclasite, quartz-mica-, quartz-sericite-, quartz-chlorite-, and quartz-graphite schist are the most common. Sample 12a, from near Port Wing, Wis., contains a large percentage of muddy-clayey intraclasts, whereas sample 29a, from Amnicon State Park, Wis., is enriched in volcanic fragments of basalt clasts that possess felsitic and micro-ophitic textures and diabase clasts of ophitic, granophyric, and graphic textures.

In the Iron River, Wis., samples, highly deformed mica and chlorite make up the bulk of the heavy minerals (table E2). In the other samples, opaque and semi-opaque minerals predominate. Zircon, tourmaline, garnet, and hornblende are common constituents. Some of the apatite and epidote grains are authigenic.

\section{Devils Island Sandstone}

The Devils Island Sandstone is a thinly bedded, wellsorted, white to buff quartzose sandstone (Morey and Ojakangas, 1982) characterized by subangular to wellrounded, medium-sized quartz grains (Tyler and others, 1940). Dickas (1986) considers it to be an almost pure orthoquartzite. The sample collected for this study at Siskiwit Falls (locality 11, fig. E2), near Cornucopia, Wis., on the west side of the Bayfield Peninsula, is a wellsorted, fine- to-medium grained, well-rounded quartz arenite in which quartz makes up about 95 percent of the major rock-forming components. This is similar to values published by Morey and Ojakangas (1982). Quartz grains are recrystallized and have abraded secondary overgrowths. Rock fragments (table E1) consist of chert, quartzite, and schist. Muscovite is the predominant heavy mineral (75 percent). Opaque and semi-opaque minerals make up about 14 percent. Tourmaline is more abundant than zircon (table E2).

\section{Chequamegon Sandstone}

The Chequamegon Sandstone is massive to thick bedded $(10-15 \mathrm{ft}$, or $3-5 \mathrm{~m})$, red, brown, or gray-andwhite-mottled arkosic to feldspathic sandstone, containing 


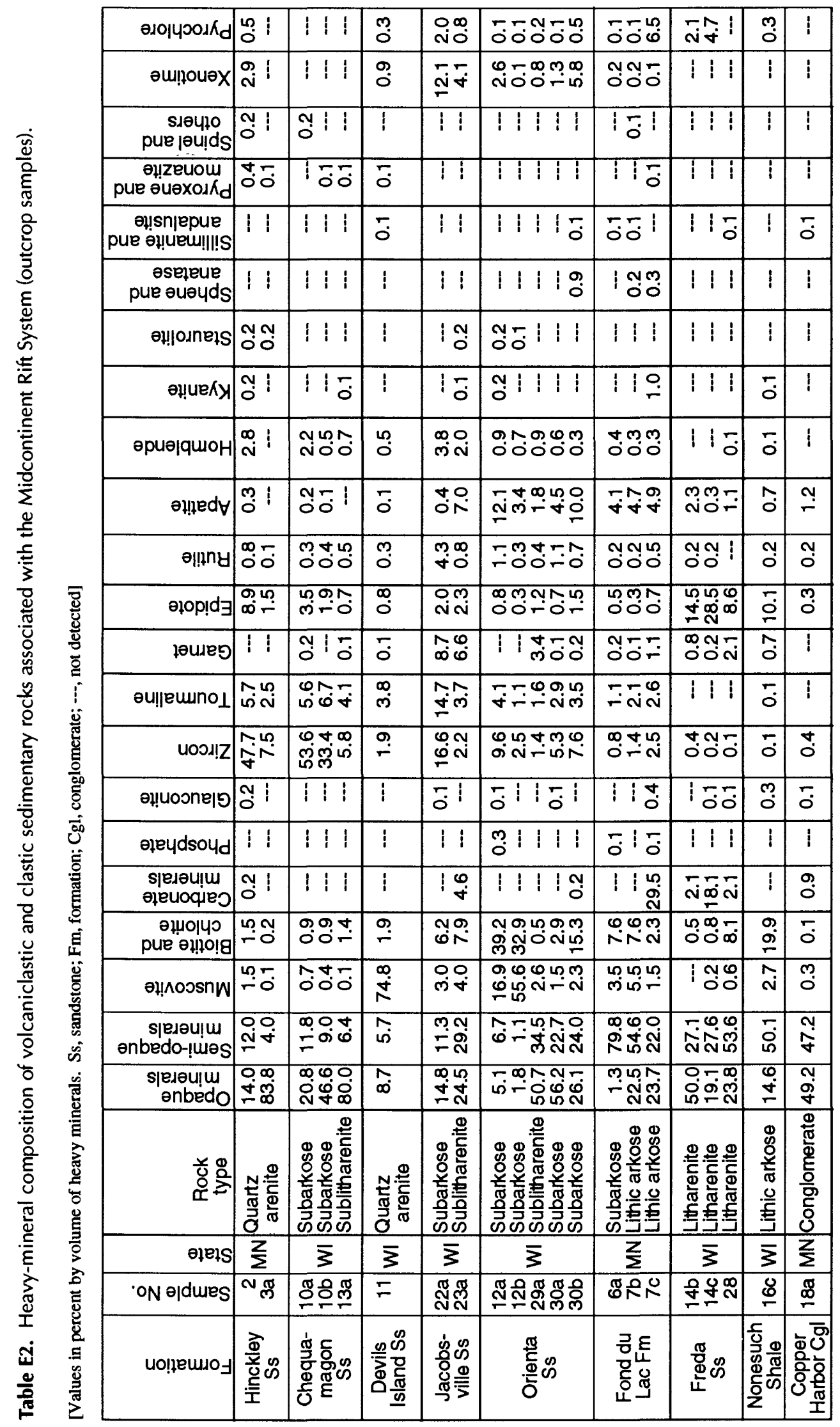




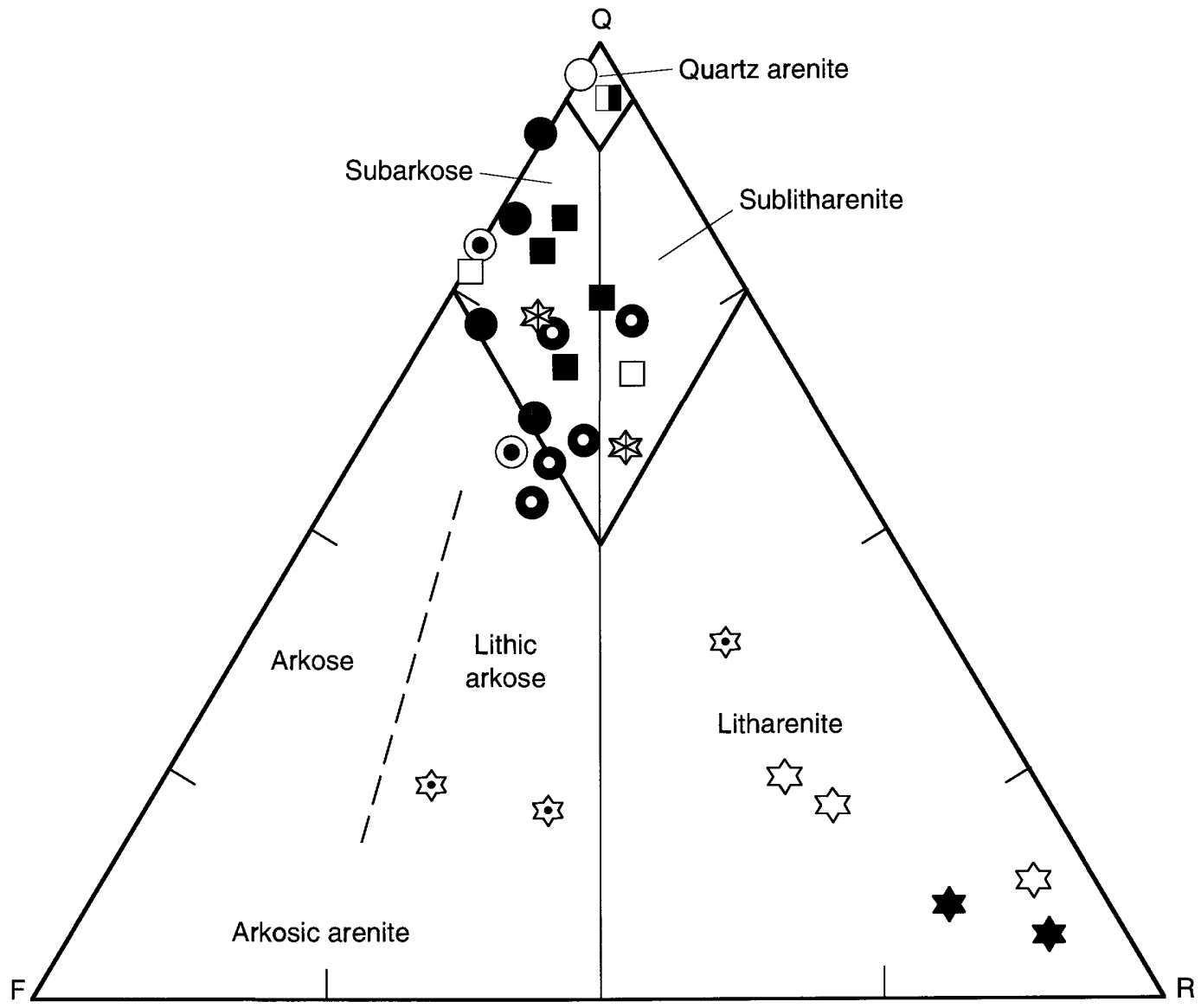

\section{EXPLANATION}
Minnesota
$\bigcirc$ Hinckley Sandstone
- Fond du Lac Formation
(- Drill core-Lonsdale \#65-1

Wisconsin

Chequamegon Sandstone

Devils Island Sandstone

Orienta Sandstone
Michigan-Wisconsin

Jacobsville Sandstone

Freda Sandstone

Nonesuch Shale

2. Copper Harbor Conglomerate

lowa

Drill core-Precambrian "red clastics" (Lehman \#1, McCallum \#A-1)

Figure E3. Petrographic composition of Precambrian sedimentary rocks of the northern part of the Midcontinent Rift System (diagram after Pettijohn and others, 1972), Q, quartz; F, feldspar; R, rock fragments.

minor interbedded red shale and some conglomerate (Morey and Ojakangas, 1982; Tyler and others, 1940). The unit is fairly mature, containing an average of 83 percent quartz, 14 percent feldspar, and 3 percent labile rock fragments (Myers, 1971). For this study, samples were collected from two localities near Washburn, Wis., on the east side of the Bayfield Peninsula (localities 10 and 13, fig. E2). One of the samples (table E1) contains about 20 percent labile constituents, but the other constituents fall within the range of reported values (fig. E3). Rock fragments are rare in the subarkoses $(0.8$ percent in sample $10 \mathrm{~b})$, but are common in the sublitharenitic phases of the unit (as much as 15.8 percent in sample 13). The fragments consist primarily of metamorphic rock (fig. E4), but also include quartzite, cataclasite, quartz-graphite-, quartzsericite-, and quartz-muscovite schist; quartz-ferruginous 
rocks (iron-formation?), and minor, slightly metamorphosed quartz-sericite mudstone. Volcanic rock fragments consist of altered basalt having an ophitic and microophitic texture. Only a few fragments of thyolite and diabase, which has an unusual granophyric texture, are present. Sedimentary rock fragments consist mainly of chert and agate.

The heavy-mineral fraction in the subarkosic samples consists of resistant minerals, such as zircon and opaque minerals, and lesser amounts of tourmaline, epidote, and hornblende. The sublitharenitic sample contains mostly opaque minerals, but other heavy minerals similar to those found in the subarkoses are present. The heavy-mineral composition of four samples from the same formation from near Bayfield, Wis. (about $12 \mathrm{mi}(18 \mathrm{~km})$ north of Washburn) collected and analyzed by Tyler and others (1940) is mainly ilmenite (67-80 percent), leucoxene (10 20 percent), and zircon (4-11 percent), and lesser amounts of tourmaline, anatase, apatite, and rutile.

\section{Bayfield Group Equivalent Rocks}

Sandstone units that are believed to correlate with formations exposed in Wisconsin have different names in the outcrop area in Minnesota. Nondeposition or erosion of rocks equivalent to the Chequamegon Sandstone of Wisconsin is the reason that these rocks apparently do not occur in Minnesota (Morey and Ojakangas, 1982).

Sandstone units in Michigan to the east and south of the Keweenaw fault (fig. E2) were assigned to the Jacobsville Sandstone by Lane and Seaman (1907). Most workers consider the unit to correlate with the Bayfield Group because of studies of the heavy-mineral suite by Tyler and others (1940), similarities of the sediment, mineral, and clay matrix to the Fond du Lac Formation as noted by Kalliokoski (1982), and analyses of paleomagnetic pole positions (Roy and Robertson, 1978) suggesting that the unit is younger than the Freda Sandstone.

\section{Fond du Lac Formation}

The Fond du Lac Formation is characterized by lenticular beds of very fine grained to coarse-grained, poorly sorted arkosic sandstone and siltstone interbedded with locally thick units of shale and mudstone (Morey, 1967, 1972). Conglomerate is scattered throughout the formation.

Sandstone in the Fond du Lac Formation is characterized by its low rank of maturity, the high content of feldspar and rock fragments, muddy-clayey intraclasts, deformed mica flakes, quartz grains recrystallized in preferred directions, complex composition of the cement, and relatively high content of authigenic minerals.
This rock unit was examined and sampled at Fond du Lac Park (locality 7), at Jay Cook State Park (locality 8), and along Mission Creek (locality 6), all in the Duluth area, Minnesota (fig. E2). At Jay Cook State Park a 60-ft (18-m)-thick conglomeratic horizon is present above an angular unconformity with the underlying Penokean-age (Early Proterozoic) Thomson Formation of the Animikie Group. Clasts of milky-white vein quartz, as much as 6 in. $(15 \mathrm{~cm})$ in diameter predominate, but clasts composed of chert, quartzite, graywacke, and slate, some of it derived from the underlying Thomson Formation, are also present. The rocks sampled as part of this study consist of fine- to medium-grained subarkose, lithic arkose, coarse-grained to very coarse grained conglomeratic sublitharenite, and basal conglomerate. Our data plot on a triangular Q-F-R diagram (fig. E3) in a cluster in the fields assigned to these rock types and compare well with data reported by Morey and Ojakangas (1982). The framework mineralogy ranges from 38 to 53 percent for quartz, from 9 to 19 percent for feldspar, and from 8 to 14 percent for rock fragments (table E1). With the exception of quartz, these values are similar to those reported by Morey and Ojakangas (1982) on the basis of earlier studies of surface and subsurface samples in Minnesota. They report an average of 77 percent quartz in the framework. Quartz grains are well rounded in the coarse-grained and conglomeratic sandstone. They are poorly rounded and angular in the fine- to medium-grained sandstone. Only a few quartz grains have abraded, thin secondary overgrowth rims. The feldspars consist mostly of unaltered microcline, together with orthoclase and perthite. No plagioclase has been found in any of the samples. Rock fragments are mostly of metamorphic origin and consist of quartz-mica and quartz-sericite schist, fine-grained quartzite, and quartz-ferruginous rock; the latter may have been derived from iron-formation. Chert and clay intraclasts make up the bulk of the sedimentary rock fragments. Basaltic, diabasic, and devitrified volcanic rock fragments are minor components. Only a few fragments of granitic or gneissic rocks were identified. Phyllosilicates (2.9-3.7 percent by volume), nearly all of which are strongly deformed, consist mostly of secondary chlorite, with minor muscovite, and both fresh and altered biotite. The heavymineral fraction is mostly semi-opaque and opaque minerals (table E2). Other heavy minerals are zircon, tourmaline, garnet, epidote, hornblende, and apatite, part of which are authigenic.

\section{Hinckley Sandstone}

In outcrop the formation is a thick- to massive-bedded, fine- to coarse-grained, pale-red to light-pinkish-gray or brownish-gray quartzose sandstone (Morey and Ojakangas, 1982). The rocks are well exposed in a number of localities along the Kettle River in eastern Minnesota. Outcrops of Hinckley Sandstone were examined and sampled at 


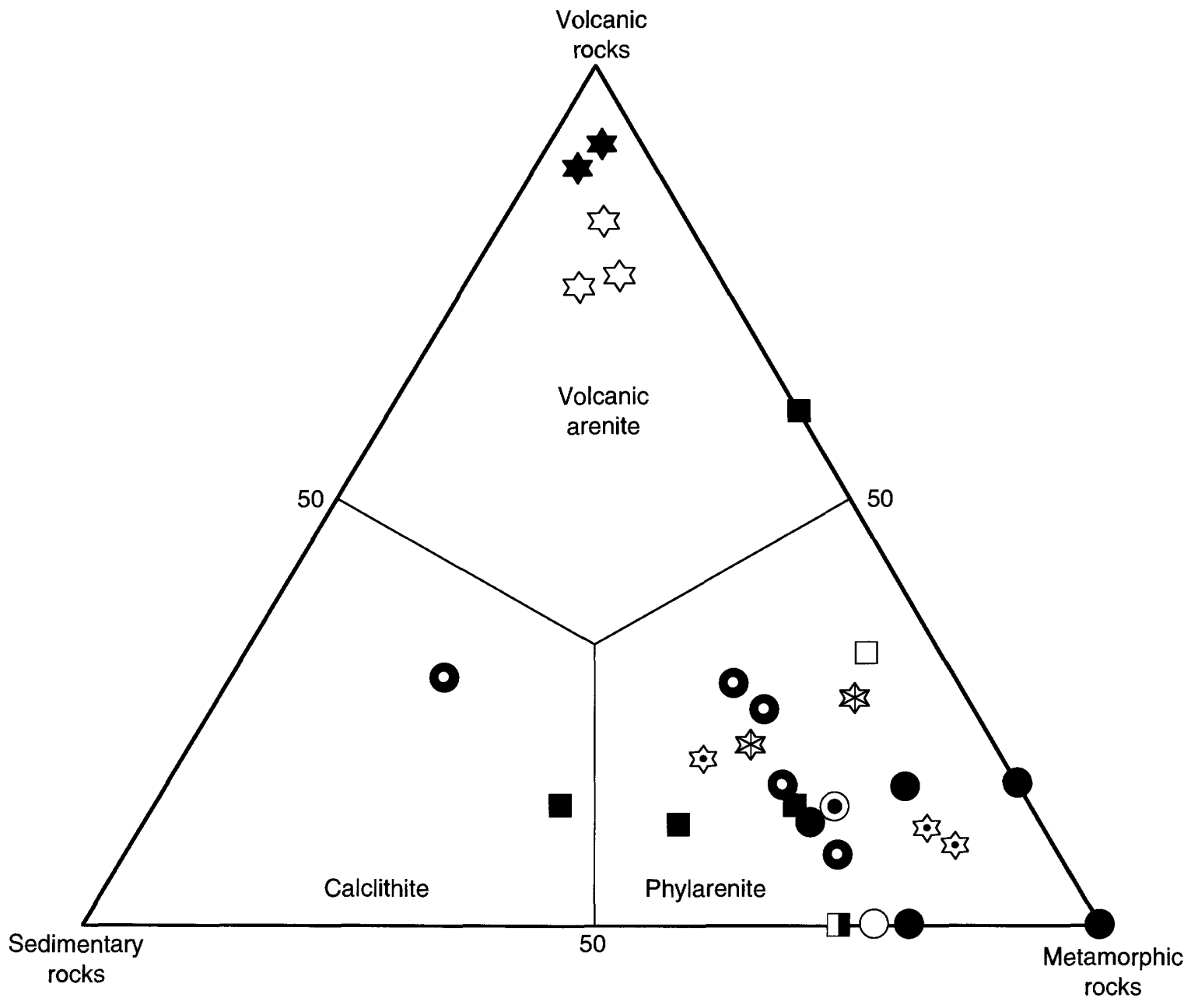

EXPLANATION

Minnesota

Hinckley Sandstone

- Fond du Lac Formation

( Drill core-Lonsdale \#65-1

Wisconsin

Chequamegon Sandstone

Devils Island Sandstone

Orienta Sandstone
Michigan-Wisconsin

Jacobsville Sandstone

Freda Sandstone

¿্] Nonesuch Shale

Copper Harbor Conglomerate

lowa

Drill core-Precambrian "red clastics"

(Lehman \#1, McCallum \#A-1)

Figure E4. Petrographic composition of Precambrian sedimentary rocks of the northern part of the Midcontinent Rift System based on the composition of their constituent rock fragments (diagram after Pettijohn and others, 1972).

Hinckley (locality 3a), and in a roadcut near Askov (locality 3b), all in Minnesota (fig. E2). At the last location the basal Hinckley Sandstone, exposed along a creek at the city park, is a fine- to medium-grained quartz arenite in which the quartz grains are rounded to angular. Rock fragments and feldspar grains are noticeably more abundant at this location than at other places, where the rock is a more mature quartz arenite, the quartz averaging about 96 percent of the framework grains (Tryhorn and Ojakangas, 1972). Feldspar and rock fragments generally constitute 
less than 5 percent of the rock (fig. E3, table E1). Rock fragments are chert and quartzite. Heavy minerals are opaque minerals, zircon, tourmaline, hornblende, and minor rutile, kyanite, and pyroxene. Secondary xenotime and pyrochlore make up 3.4 percent of the sample from Robinson Park, near Hinckley.

\section{Jacobsville Sandstone}

The Jacobsville Sandstone is a thick fluvial sequence $(2,800 \mathrm{ft}(850 \mathrm{~m})$ or more) of feldspathic and quartzose sandstone, conglomerate, siltstone, and shale. The unit occurs east and south of the Keweenaw fault (fig. E2) and does not contain any lava flows or cross-cutting dikes (Kalliokoski, 1982). Generally, the unit varies from subarkose to sublitharenite, in which quartz is derived from both metamorphic and volcanic sources, rock fragments are mafic or felsic rocks and schist, and microcline is fresh, while plagioclase is fresh to altered (Kalliokoski, 1982).

For this study we sampled and examined rocks from the east side of the Keweenaw Peninsula at Gay (locality 22) and at Baraga (locality 23), both in Michigan. The rocks are fine- to medium-grained subarkose, fine- to medium- to coarse-grained sublitharenite, and very coarse grained conglomeratic litharenite (fig. E3). The cement (16.9-17.7 percent) consists mainly of clay, and locally additional quartz, iron oxide, and calcite-dolomite. In the two samples (22a and 23a) that were point counted, quartz makes up from 42.8 to 48.3 percent, feldspar from 12.7 to 13.3 percent, and rock fragments from 6.8 to 16.8 percent (table E1). Hamblin (1958) reported a larger percentage of quartz (75 percent or more) in the rocks he examined, but the reported feldspar content is similar (15 percent).

The smaller quartz grains are poorly rounded, and the larger quartz grains and pebbles are well rounded. Feldspar is mostly fresh microcline, with lesser amounts of altered microcline, orthoclase, and perthite. Several plagioclase feldspar grains were found in sample 22a (table E1). Metamorphic rock fragments, consisting of various types of schist and quartz-ferruginous rocks (ironformation?), predominate. Minor amounts of volcanic and sedimentary rock fragments are also present. Similar findings were reported by Kalliokoski (1982).

The heavy-mineral fraction consists of opaque and semi-opaque minerals, and appreciable amounts of zircon, tourmaline, garnet, hornblende, rutile, epidote, and apatite. A characteristic mineralogical feature of the Jacobsville Sandstone is the high content of secondary xenotime and pyrochlore. Sample 22a (table E2) contains the highest concentration of these minerals encountered in this study.

Figure E5 (facing column). Generalized geologic map showing the subsurface distribution of Keweenawan rocks in southern Minnesota, lowa, and eastern Nebraska, and the location of drill holes discussed in text.

\section{PETROGRAPHIC STUDY OF SUBSURFACE SAMPLES}

Samples of core and cuttings from exploration drill holes in Minnesota, Iowa, Nebraska (fig. E5), and Kansas (fig. E6) were collected in the second phase of the study. The petrographic characteristics of the samples are described below for each state.

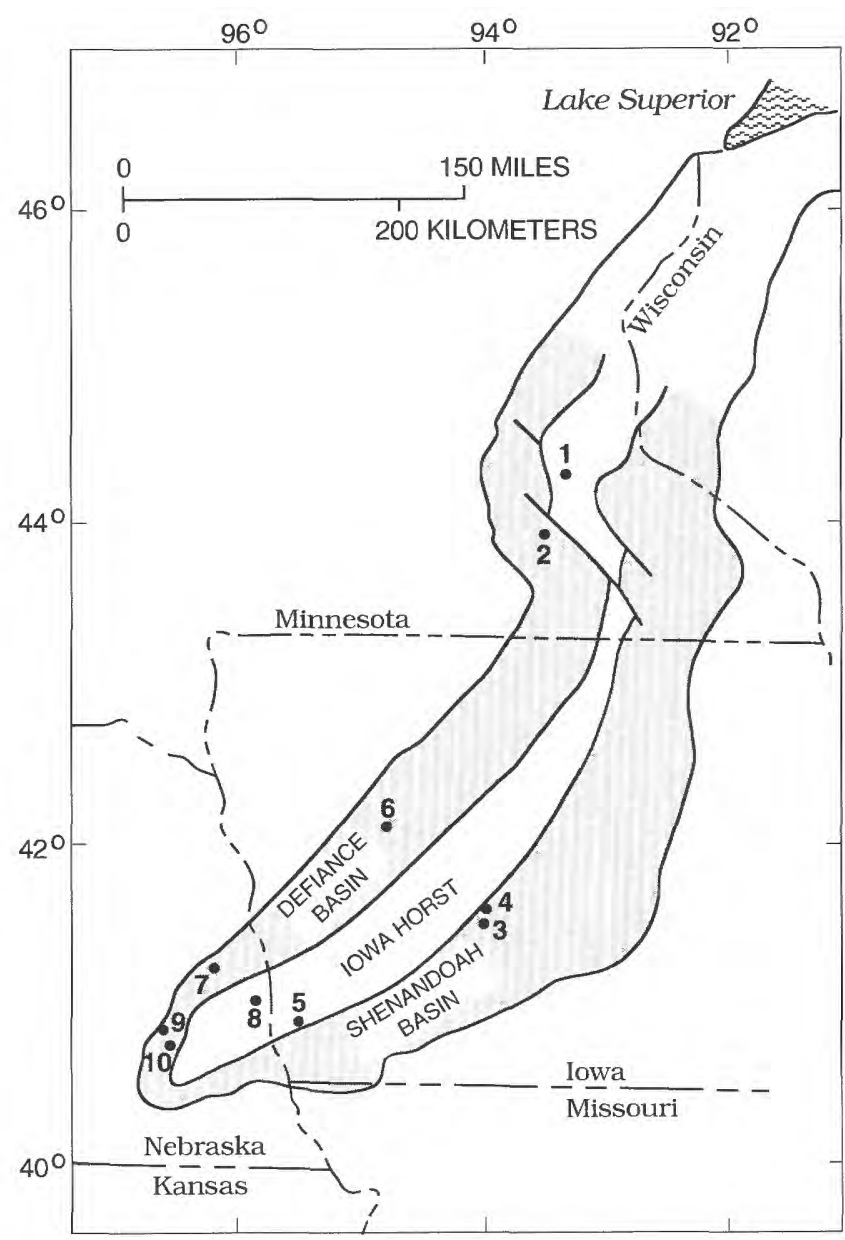

3 Drill hole

EXPLANATION

1. Lonsdale \#65-1 NW1/4SW1/4SW1/4 sec. 14, T. 112 N., R. 21 W. 2. Schuette \#1 3. B. Lehman \#1 SW1 $14 N W 1 / 4 N W 1 / 4 \mathrm{sec} .18, T .79$ N., R. $27 \mathrm{~W}$

4. McCallum \#A-1 NW1/4NW1/4SW1/4 sec. 5, T. 79 N., R. 27 W.

5. Fitzgerald \# $1 \quad W 1 / 2$ sec. $21, T .71$ N., R. 41 W.

6. Eischeid \#1 NW1/4NW1/4SE1/4 sec. 6, T. 83 N., R. 35 W.

7. Koutney \#1 SE1/4SE1/4NW1/4 sec. 11, T. 15 N., R. 7 E

8. Schroeder \#1 E1/2 sec. 26, T. 11 N., R. 12 E.

9. Ihde \#1

10. Sullivan \# 1 SE $1 / 4$ NW1/4 sec. 14, T. 10 N., R. 4 E. NW $1 / 4$ NW $1 / 4$ NW $1 / 4$ sec. 36 , T. 9 N., R. 5 E.

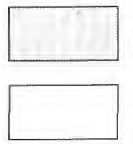

Sedimentary rocks (Bayfield Group and equivalent rocks)

Volcanic and associated sedimentary rocks (Oronto Group and Solor Church Formation) 


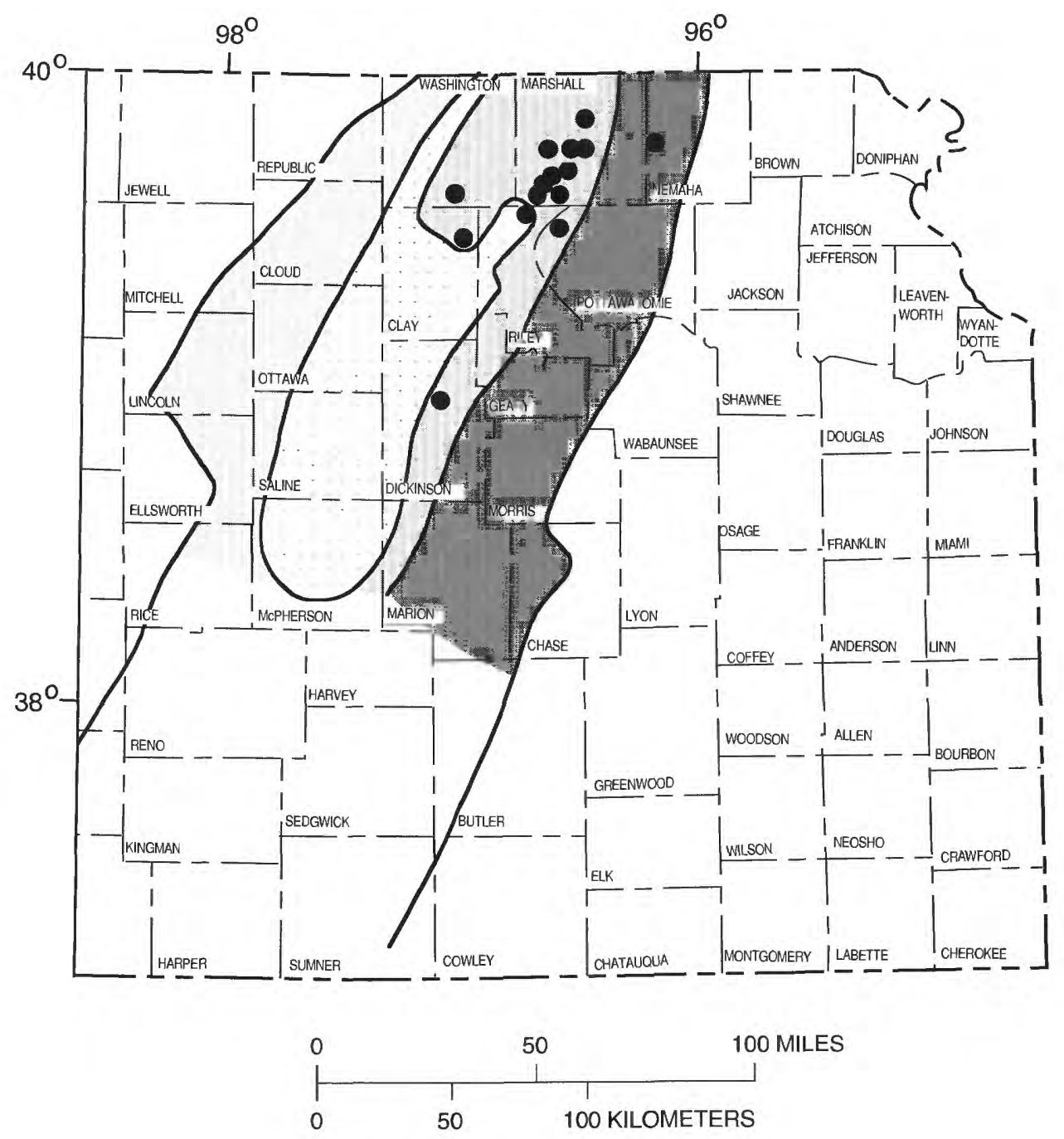

EXPLANATION

Area underlain by predominantly granitic rocks

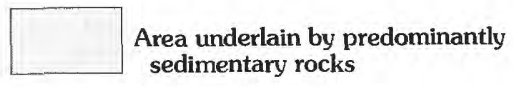

Drill hole locations

Area underlain by predominantly mafic volcanic rocks

Figure E6. Generalized distribution of Keweenawan-age rocks in Kansas and approximate location of drill holes from which samples were taken (for legal description of the drill-hole locations, see fig. E7).

\section{Minnesota}

In southern Minnesota, Keweenawan rocks are buried beneath younger sedimentary rocks. Petrographic studies of subsurface samples by Morey (1977) enabled him to make stratigraphic correlations with Keweenawan rocks in Wisconsin and Michigan. As part of the MSCM Project, selected segments of core from five drill holes were examined and described (R.R. Anderson, Iowa Geological Survey; R.M. McKay; P. Berendsen; A. Barczuk; G.B.
Morey; P. McSwiggin; and M.P. Carlson, written commun., 1987). Samples from two drill holes were collected for petrographic studies and heavy-mineral analysis to aid in tentative stratigraphic correlations with rocks farther to the south. One of the drill holes, the Lonsdale \#65-1 (fig. E5), is located in the central part of the rift (St. Croix horst) and penetrates rocks of the Solor Church Formation (fig. E1). These rocks were designated as the type locality of the formation by Morey (1977) and are nowhere exposed in the state. The other drill hole, 
Schuette \#1 (fig. E5), is located on the rift shoulder and penetrates younger rocks equivalent to the Bayfield Group, possibly the Orienta Sandstone.

Core samples were collected from the Lonsdale \#65-1 drill hole in Rice County (fig. E5) from the following depths: $900,918,934,947,1,279,1,310,2,507,2,524$, and 2,774 ft. Detailed petrographic analyses were performed on samples from the 918- and the 1,310-ft depths (table E1).

At $918 \mathrm{ft}$ the rock is a fine- to medium-grained, weakly cemented, clayey subarkose having a bimodal grain-size distribution. Fine-grained, angular quartz is associated with the clayey matrix, and medium-grained quartz grains occur in the very porous primary matrix. Feldspar (mainly euhedral), authigenic microcline, and a small amount of altered muscovite are also present. Rock fragments consisting of quartzite, gneiss, and some chert make up less than 1.0 percent. Heavy minerals such as zircon, tourmaline, and epidote are present. Thin sections of the rocks at 900 and $934 \mathrm{ft}$ show them to be quartz arenite, richer in quartz than the rock described above. The rock at $947 \mathrm{ft}$ is a ferruginous shale interbedded or intermixed with mudstone, which is enriched in detrital quartz and altered potassium feldspar.

The rock at $1,310 \mathrm{ft}$ is a very fine grained, laminated, crossbedded lithic arkose. It is poorly cemented with porous clay. Angular quartz having secondary overgrowths is the principal mineral. Unaltered microcline and minor kaolinized plagioclase make up as much as 17.2 percent of the rock by volume. Metamorphic rocks (quartz-mica and quartz-chlorite schist) and lesser amounts of sedimentary and volcanic rocks are the major fragments. The rock contains altered biotite and muscovite as well as detrital or authigenic chlorite. Heavy minerals are rare. Authigenic epidote predominates over zircon, tourmaline, and garnet (table E3).

The rock at $1,279 \mathrm{ft}$ is a dark-green, green, and red shale containing irregular intercalations of mudstone, which may be classified as very fine grained arkose and arkosic wacke containing altered feldspar (as much as 20 percent), and as much as 20 percent muscovite and chlorite. The three samples from below $2,500 \mathrm{ft}$ are shale, mudstone, and siltstone. The rock is as much as 30 percent quartz, and potassium feldspar and plagioclase make up as much as 10 percent. The heavy-mineral fraction commonly contains opaque minerals, zircon, tourmaline, rutile, sphene, and epidote.

Our analysis indicates that the Keweenawan clastic unit in the Lonsdale \#65-1 drill hole decreases in maturity with depth. The petrological composition of the rocks tentatively suggests to us that they are similar to those of the Oronto Group in Wisconsin and Michigan. Morey (1977) assigned the rocks penetrated by the drill hole to the stratigraphically equivalent Solor Church Formation and designated these rocks as the type locality. Morey
(1977) suggested that the rocks were deposited in an alluvial-plain-lacustrine environment. Seismic evidence indicates that an additional $1,300 \mathrm{ft}(395 \mathrm{~m})$ of older Keweenawan rocks are present at this location (Mooney and others, 1970). Some constituents of the heavymineral suite (especially epidote) and the occurrence of shale in the section may also indicate a similarity to the Solor Church Formation. On the basis of the total amount of quartz and the absence of plagioclase feldspar, we think that the rocks above about $1,200 \mathrm{ft}$ may belong in the Bayfield Group.

The Fond du Lac Formation overlying the Solor Church Formation (fig. E1) was examined in the Schuette \#1 drill hole, in Waseca County. A heavy-mineral concentrate was prepared from a sample from $2,305.0 \mathrm{ft}$ deep. The rock is a dark-red subarkose containing abundant small white spots (kaolinite), similar to equivalent-age rocks that crop out farther north in the basin west of the horst. The composition of the heavy-mineral concentrate, including the small amount of epidote and larger concentrations of tourmaline and zircon, suggests that the rock unit may indeed be the correlative of the older rocks in the Bayfield Group, possibly the Orienta Sandstone (table E3). Sedimentary structures described by Morey (1977) indicate that the rocks were deposited in a fluvial, shallowwater, deltaic environment.

\section{lowa}

Keweenawan clastic rocks, informally referred to as "red clastics," were penetrated in five holes drilled prior to 1987. The Amoco M.G. Eischeid \#1 (Eischeid \#1) drill hole, completed in 1987 and located in the Defiance Basin west of the Iowa horst (fig. E5), is the only drill hole that penetrated the complete Keweenawan "red clastic" sequence (Witzke, 1990). Witzke (1990) was able to correlate the informally named upper "red clastic" sequence with rocks of the Bayfield Group and the lower "red clastic" sequence with rocks of the Oronto Group.

For our study, core from two drill holes (B. Lehman \#1 and McCallum \#A-1) in the Shenandoah Basin, east of the lowa horst, and cuttings from the Fitzgerald \#1 drill hole on top of the Iowa horst, in the southwestern part of the state (fig. E5), were analyzed. Rocks of the Cambrian Mount Simon Sandstone (Witzke, 1990) and of the upper part of the Bayfield Group (Chequamegon Sandstone) were penetrated by the drill holes. The Mount Simon Sandstone, the basal Cambrian sandstone present in eastern Iowa, may be more than $1,000 \mathrm{ft}$ thick in the basins east of the Iowa horst (Witzke, 1990). These rocks may be difficult to distinguish from the sandstone in the upper part of the Chequamegon Sandstone and equivalent rocks elsewhere along the rift. On top of the Iowa horst, the Mount Simon Sandstone is generally less than $100 \mathrm{ft}$ thick (Witzke, 1990). 
Table E3. Heavy-mineral composition of core and cuttings from drill holes in Minnesota, lowa, and Kansas.

[Values in percent by volume of heavy minerals. ---, not detected]

\begin{tabular}{|c|c|c|c|c|c|c|c|c|c|c|c|c|c|c|c|c|c|c|c|c|c|c|c|c|}
\hline 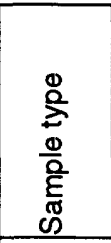 & 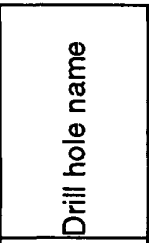 & 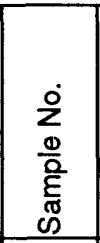 & 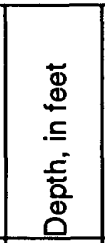 & 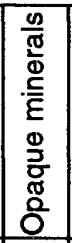 & 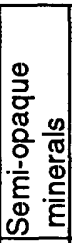 & 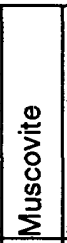 & 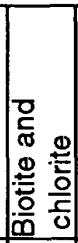 & 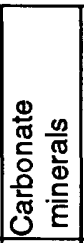 & 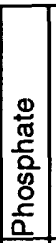 & 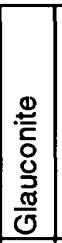 & $\begin{array}{c}\overline{0} \\
\stackrel{0}{N} \\
\end{array}$ & 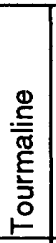 & 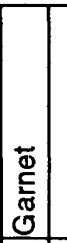 & $\begin{array}{l}\Phi \\
\text { 음 } \\
\text { யி }\end{array}$ & 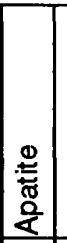 & 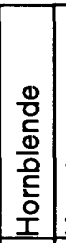 & 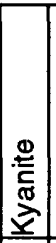 & 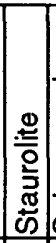 & 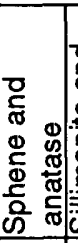 & 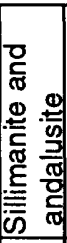 & 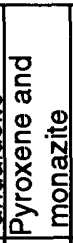 & 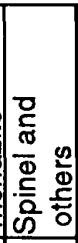 & 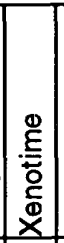 & $\begin{array}{l}\frac{0}{2} \\
\frac{0}{5} \\
\frac{1}{2} \\
2 \\
\end{array}$ \\
\hline Core & $\begin{array}{c}\text { McCallum } \\
\# A-1\end{array}$ & $\begin{array}{l}M-2 \\
M-4 \\
M-5\end{array}$ & \begin{tabular}{|l|}
2990 \\
3012.5 \\
3014 \\
\end{tabular} & \begin{tabular}{|l|}
16.5 \\
45.1 \\
12.5 \\
\end{tabular} & \begin{tabular}{|l|}
35.3 \\
21.2 \\
18.2 \\
\end{tabular} & \begin{tabular}{r|}
9.4 \\
7.2 \\
12.5 \\
\end{tabular} & \begin{tabular}{|r|}
0.4 \\
4.5 \\
20.4 \\
\end{tabular} & $\begin{array}{c}\ldots \\
4.8 \\
\ldots . .-\end{array}$ & \begin{tabular}{|c|}
.- \\
$\cdots .4$ \\
0.4 \\
\end{tabular} & \begin{tabular}{|c|}
-- \\
$\cdots$ \\
1.1 \\
\end{tabular} & \begin{tabular}{|l|}
19.8 \\
11.1 \\
14.7 \\
\end{tabular} & \begin{tabular}{l|}
1.5 \\
2.7 \\
1.9 \\
\end{tabular} & $\begin{array}{l}0.7 \\
0.1 \\
0.1\end{array}$ & $\begin{array}{l}1.7 \\
0.7 \\
2.0\end{array}$ & $\begin{array}{l}-. \\
--1 \\
8.6\end{array}$ & \begin{tabular}{l|}
0.1 \\
0.3 \\
0.1
\end{tabular} & \begin{tabular}{|c|}
-- \\
$-\cdots$ \\
$-\cdots$ \\
\end{tabular} & $-\cdots$ & $\begin{array}{c}-- \\
--- \\
--\end{array}$ & $\begin{array}{l}-- \\
--- \\
--- \\
\end{array}$ & $\begin{array}{r}0.1 \\
\ldots .- \\
-. .\end{array}$ & $\begin{array}{l}-\cdot \\
--- \\
--- \\
\end{array}$ & $\begin{array}{l}1.3 \\
1.5 \\
4.5 \\
\end{array}$ & $5 \begin{array}{l}12.9 \\
0.3 \\
1.2\end{array}$ \\
\hline Core & $\begin{array}{c}\text { Lonsdale } \\
\# 65-1\end{array}$ & Lo-6 & 1310 & 31.5 & 43.2 & 2.7 & 2.0 & $\cdots$ & $\cdots$ & $\cdots$ & 2.1 & 0.4 & $1.5 \mid 1$ & 12.7| & 3.0 & -- & $\cdots$ & -- & 0.1 & $\cdots$ & $\cdots$ & -. & 0.4 & \\
\hline Core & $\begin{array}{c}\text { B. Lehman } \\
\# 1\end{array}$ & $\begin{array}{l}L \mathrm{Lm}-2 \\
\mathrm{Lm}-3\end{array}$ & $\begin{array}{l}2927 \\
2947 \\
\end{array}$ & $\begin{array}{r}8.0 \\
37.0 \\
\end{array}$ & $\begin{array}{r}9.0 \\
39.3 \\
\end{array}$ & \begin{tabular}{|r|}
16.5 \\
2.0 \\
\end{tabular} & $\begin{array}{r}45.0 \\
7.8 \\
\end{array}$ & 0.2 & \begin{tabular}{|c|}
0.1 \\
$\ldots .$. \\
\end{tabular} & \begin{tabular}{|l|}
0.9 \\
0.2 \\
\end{tabular} & $\begin{array}{l}5.2 \\
3.8 \\
\end{array}$ & \begin{tabular}{|l|}
2.3 \\
1.7 \\
\end{tabular} & \begin{tabular}{|c|}
-.1 \\
0.1
\end{tabular} & $\begin{array}{l}0.9 \\
1.1\end{array}$ & \begin{tabular}{|l|}
8.3 \\
4.6 \\
\end{tabular} & \begin{tabular}{|l|}
0.3 \\
0.3 \\
\end{tabular} & \begin{tabular}{|l|}
$\ldots$ \\
$\ldots-$. \\
\end{tabular} & $\ldots$ & $\cdots$ & $\ldots$ & $\cdots$ & $\cdots$ & $\begin{array}{l}2.4 \\
1.3 \\
\end{array}$ & \begin{tabular}{|l|}
0.1 \\
0.1 \\
\end{tabular} \\
\hline $\begin{array}{c}\text { Core } \\
\text { W } 1 / 2 \\
\text { NW NE }\end{array}$ & $\begin{array}{c}\text { Schuette } \\
\# 1\end{array}$ & S-1 & 2305 & 2.5 & 26.2 & 0.6 & 0.5 & 1.2 & $\cdots$ & - & 1.2 & 1.0 & 1.7 & 0.4 & 3.7 & 0.1 & - & -- & 0.1 & - & $\cdots$ & 0.1 & 9.8 & 0.3 \\
\hline Cuttings & Finn \#1 & FC $5 / 6$ & 3225 & 47.4 & 26.6 & 0.7 & 1.2 & 5.4 & $-\cdots$ & 0.1 & 5.9 & 0.8 & 0.8 & 1.5 & 6.0 & 0.1 & $\cdots$ & $\ldots$ & $\cdots$ & $\cdots$ & -- & $\cdots$ & 2.0 & 0.2 \\
\hline
\end{tabular}

In the B. Lehman \#1 drill hole in Dallas County, Precambrian rocks from 2,924 to $2,964 \mathrm{ft}$ were cored. The contact between the Cambrian Mount Simon Sandstone and the Precambrian "red clastics" was picked at 2,924 ft (R.R. Anderson, Iowa Geological Survey; R.M. McKay; P. Berendsen; A. Barczuk; G.B. Morey; P. McSwiggin; and M.P. Carlson, written commun., 1987). Thin sections were prepared from samples from depths of 2,922, 2,927, 2,947 , and 2,956.5 ft. The first three samples are fine- to coarse-grained, poorly sorted subarkose, some intermixed with varicolored mudstone and conglomeratic sandstone. The quartz content of the rock varies from 20.0 to 70.0 percent, and it is commonly recrystallized (table E1). Altered feldspar (as much as 20.0 percent) consists of microcline and perthite, and minor orthoclase. Mica and chlorite (as much as 5.0 percent) is present at $2,947 \mathrm{ft}$. The red and greenish siltstone at $2,956.5 \mathrm{ft}$ contains as much as 30.0 percent muscovite, biotite, and detrital chlorite. In addition to opaque and semi-opaque minerals, zircon, apatite, epidote, tourmaline, and glauconite are present in the samples (table E3). The petrographic and heavy-mineral composition indicate that these rocks are similar to those in the lower part of the Bayfield Group, possibly the Orienta Sandstone.

The McCallum \#A-1 drill hole is located $2 \mathrm{mi}(3.2 \mathrm{~km})$ northeast of the B. Lehman \#1 drill hole in Dallas County. The contact between the Upper Cambrian Mount Simon Sandstone and the Keweenawan "red clastics" was picked at 3,009.3 $\mathrm{ft}$ (R.R. Anderson, Iowa Geological Survey; R.M. McKay; P. Berendsen; A. Barczuk; G.B. Morey; P. McSwiggin; and M.P. Carlson, written commun., 1987). Thin sections of samples from depths of 2,967, 2,990, $3,008.5,3,012.5$, and $3,014 \mathrm{ft}$ were studied. The first three samples are from the Mount Simon Sandstone and are fine- to coarse-grained subarkose to arkose, in some places conglomeratic. Quartz, most of it recrystallized, predominates, whereas microcline and orthoclase are subordinate (as much as 10 percent; table E1). The sample from 2,967 $\mathrm{ft}$ contains only a few zircon and tourmaline grains. The rock at $3,012.5 \mathrm{ft}$ is a medium-grained subarkose very similar to that at $3,008.5 \mathrm{ft}$, above the angular unconformity in the Mount Simon Sandstone.

The contact between the Mount Simon Sandstone and the Chequamegon Sandstone is interpreted to be at about $3,013 \mathrm{ft}$. The underlying Chequamegon Sandstone at $3,014 \mathrm{ft}$ is a fine-grained subarkose to arkose, mixed with minor subarkosic wacke or mudstone. Phyllosilicates, preferentially concentrated along bedding planes, make up as much as 10 percent. Zircon, tourmaline, epidote, and rutile grains are important constituents (table E3). The amount of feldspar, phyllosilicates, and fragments of metamorphic and sedimentary rocks also suggests a similarity to the Chequamegon Sandstone.

We examined two samples of cuttings from a depth of 2,595-2,605 ft in the Fitzgerald \#1 drill hole, located on top of the Iowa horst in Mills County (fig. E5), southwestern Iowa. The rock is a fine- to coarse-grained arkose cemented with clay. Microcline, orthoclase, and a few grains of albite make up as much as 20 percent of the rock.

In the lower $5 \mathrm{ft}$ of the drill hole, basalt having a microophitic or insertal texture and minor basaltic tuffs and tuffites are present. The volcanic rocks have a high content of opaque minerals (as much as 5 percent). The clastic sedimentary rocks were reported to constitute the lower part of the Mount Simon Sandstone directly overlying the Keweenawan volcanics (R.R. Anderson, Iowa Geological Survey; R.M. McKay; P. Berendsen; A. Barczuk; G.B. 
Morey; P. McSwiggin; and M.P. Carlson, written commun., 1987). Our preliminary analysis of the cuttings indicates that the sedimentary rocks are similar to the Chequamegon Sandstone.

Sedimentary rocks showing petrographic characteristics similar to those of the Oronto Group were not encountered in any of the samples studied, even in the cuttings from the Fitzgerald \#1 drill hole on top of the Iowa horst. The McCallum \#A-1 and the B. Lehman \#1 are located in the Thurman-Redfield tectonic zone separating the Iowa horst from the Shenandoah Basin to the east. Because of possible complex structural relationships, the preserved Keweenawan sequence in the two holes may differ slightly. Because we did not study the petrography of the Mount Simon Sandstone, the contact with the equivalent underlying rocks of the Bayfield Group is difficult to interpret and should be considered tentative.

\section{Nebraska}

The basal Paleozoic rocks in Nebraska are sandstone that in the past has been referred to as the "Dresbach Sandstone" (Upper Cambrian), but more recently as the "Mount Simon Formation" in "Correlation Of Stratigraphic Units of North America" (COSUNA) correlation charts. Precambrian clastic sedimentary rocks associated with the Midcontinent Rift System are collectively referred to as the "red clastics." Some attempts have been made to subdivide the sequence on the basis of the primary rock type present and the color of the rock. Differentiation between Paleozoic basal sandstone and underlying Precambrian sedimentary rocks is to a large degree based on the degree of rounding and frosting of quartz grains and the scarcity of other mineral grains.

Cuttings from four drill holes were examined. Three of the holes (Koutney \#1, Ihde \#1, and Sullivan \#1) are located in the basin northwest of the central horst in Nebraska (fig. E5). The fourth hole (Schroeder (Amerada) $\# 1$ ) is located on top of the southwestern extension of the Iowa horst close to the Iowa border (fig. E5).

We examined samples from depths of 1,690-1,700, $1,730-1,740, \quad 1,790-1,800, \quad 1,890-1,895, \quad 2,260-2,270$, $2,300-2,310,2,570-2,580$, and 2,650-2,660 ft in the Koutney \#1 drill hole, in Saunders County (fig. E5).

The rocks above $2,300 \mathrm{ft}$ are characteristic of the lower Paleozoic rocks in the area, consisting of lithic arkose, clean quartz sandstone, dolomite, and oolitic ironstone in the lower part of the section. The cuttings below 2,300 ft are quartz arenite resembling rocks of the Hinckley Sandstone. Illitic and calcareous shale and some dolomite and limestone also are present in the cuttings and probably are cavings from higher up in the section.

Cuttings from a depth of $1,570-1,575 \mathrm{ft}$ in the Schroeder (Amerada) \#1 drill hole, in Cass County (fig.
E5), were examined. The rock is a fine-grained arkose cemented with calcite. Quartz of probable volcanic origin makes up the bulk of the rock, but a considerable amount of feldspar consisting of microcline, altered plagioclase, orthoclase, and a few authigenic albite crystals, are also present. Minor volcanic rock fragments consist of basalt, altered volcanic glass, and tuff. Abundant heavy minerals include epidote and opaque minerals, together with minor rutile, zircon, and hornblende. The petrographic and heavy-mineral composition of the cuttings resembles those of the lower part of the Bayfield Group or upper part of the Oronto Group.

Cuttings from a depth of $2,830 \mathrm{ft}$ in the Ihde \#1 drill hole, in Seward County (fig. E5), consist of sandstone, red hematitic shale, and a few fragments of granite-gneiss, typical of rocks of the Rice Series in Kansas.

Cuttings from a depth of 2,310-2,319 $\mathrm{ft}$ in the Sullivan \#1 drill hole, in Lancaster County (fig. E5), consist of orange to pink, partially kaolinized feldspar and mediumto coarse-grained, well-rounded quartz grains. They are typical of a rock referred to in Kansas as "granite wash," a term used to describe mostly arkosic debris directly overlying Precambrian basement rocks. These rocks are erosional detritus derived from the predominantly granitic basement and are not restricted to the area of the rift, but occur throughout the state. The granite wash ranges in age from Precambrian to Middle Pennsylvanian and may be as much as several hundred feet thick.

\section{Kansas}

Cuttings from 15 drill holes (fig. E6) were examined and described. Tentative correlations with established stratigraphic units in the Great Lakes region were made on the basis of composition of most of the cuttings in the samples (fig. E7).

Most Precambrian and, possibly, some Lower Cambrian sedimentary rocks in central and eastern Kansas have been assigned to the Rice Series. On the basis of examination of drill-hole cuttings and minor core samples from a large number of drill holes, we have found the rocks are mostly oxidized, fine- to coarse-grained arkose and subarkose, siltstone, and conglomerate. Medium- to dark-gray, partly calcareous siltstone and shale, interbedded with limestone, also are part of the sequence. Underlying the clastic rocks are middle Keweenawan mafic volcanic rocks.

Poorly cemented, fine- to medium-grained, varicolored sandstone (quartz arenite) makes up most of the section in the upper part of the Livingood \#1 drill hole (Dickinson County; figs. E6 and E7). The quartz grains in this sandstone are poorly rounded. Microcline, orthoclase, and perthite, altered to varying degrees, and minor mica are present. Some mudstone or shale is locally interbedded. 


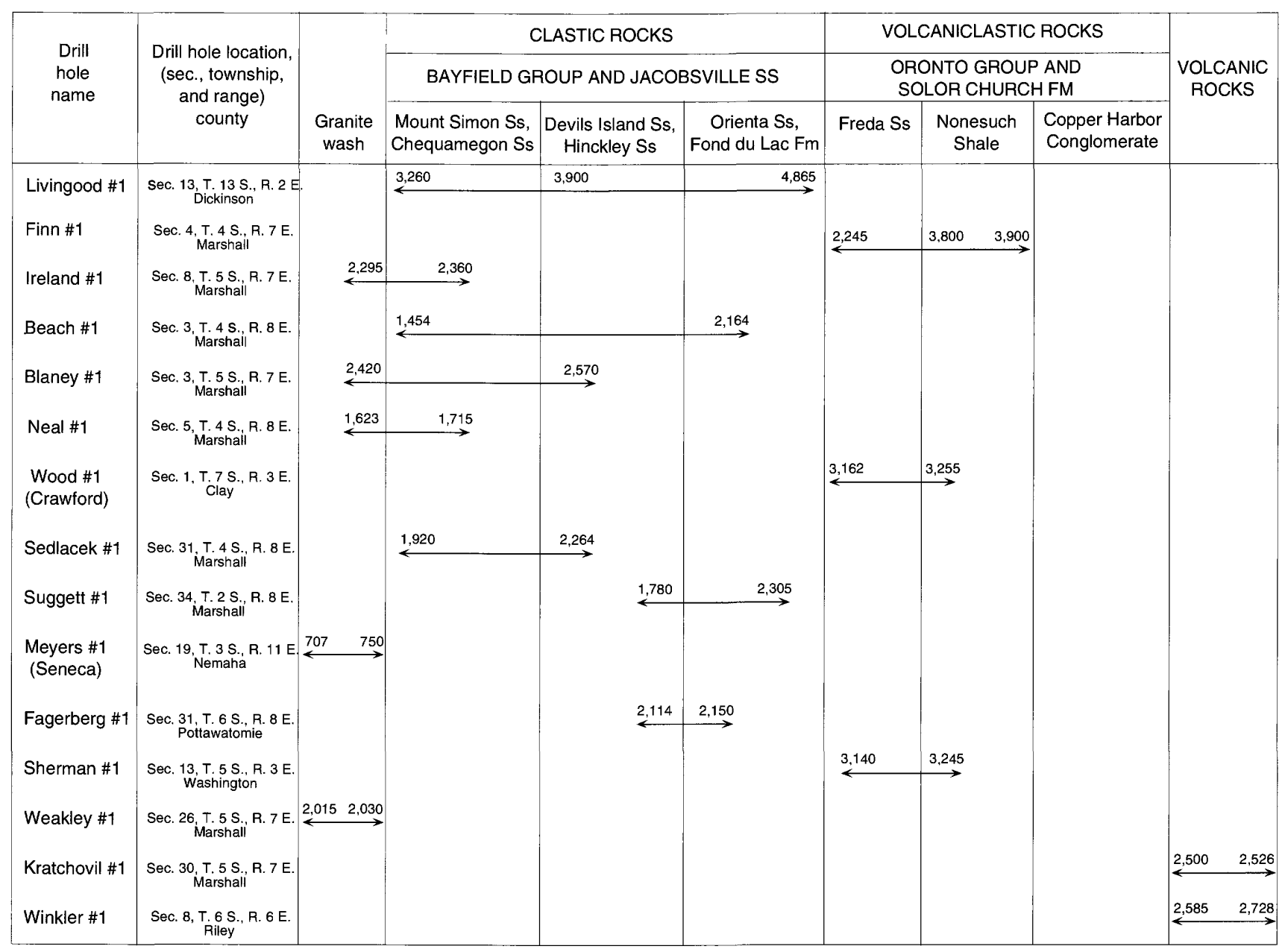

Figure E7. Preliminary stratigraphic correlation of drill-hole cuttings from Kansas with established stratigraphy in the northern part of the Midcontinent Rift System. Numbers at the end of arrows indicate the depth penetrated into the Precambrian; other numbers are approximate depths of contacts. Ss, sandstone; Fm, formation.

These rocks are assigned to the Rice Series in Kansas. Petrographically, they are similar to sedimentary rocks of the Bayfield Group or the Jacobsville Sandstone (figs. E1 and E7) and may be equivalent to the Chequamegon Sandstone or the lower part of the Mount Simon Sandstone.

Similar rocks occur in the Blaney \#1, Sedlacek \#1, Weakley \#1, Ireland \#1, Beach \#1, and Neal \#1 drill holes and in the upper part of the Suggett \#1 drill hole, all in Marshall County (figs. E6 and E7). The cuttings from the Fagerberg \#1 drill hole (Pottawatomie County) indicate that the rocks may belong to the lower part of the Bayfield Group (fig. E7). The rocks in the upper part of the Meyers \#1 drill hole (Nemaha County), above the granite basement, are most likely granite wash (fig. E7).

Cuttings below about 3,800 $\mathrm{ft}$ in the Livingood \#1 drill hole are similar to rocks of the Bayfield Group or the Jacobsville Sandstone and are tentatively correlated with rocks of the Hinckley Sandstone and the Fond du Lac Formation (figs. E1 and E7).
The cuttings at 3,800 $\mathrm{ft}$ in the Finn \#1 drill hole (Marshall County), the Sherman \#1 drill hole (Washington County), and the Wood \#1 drill hole (Clay County) contain significant amounts (more than 20 percent) of volcanic rock fragments, suggesting that they may be equivalent to rocks in the upper part of the Oronto Group (figs. E1 and E7). The cuttings from about 2,500 $\mathrm{ft}$ in the Kratchovil \#1 drill hole (Marshall County), which are of poor quality, may be derived from volcanic rocks or from fragments of volcanic rock in a clastic sedimentary rock.

\section{MODAL ANALYSIS}

There are major petrographic differences between the older volcaniclastic sedimentary rocks (Bayfield Group) and the younger arkosic rocks (Oronto Group). The psammitic volcaniclastic sedimentary rocks are exclusively litharenite and lithic arkose, whereas the arkosic rocks are 
mainly subarkose. According to the classification scheme of Pettijohn and others (1972), the clastic rocks plot in the quartz-rich sector of the triangular diagram (fig. E3), and most fall in the left, or arkosic, part of the sector. Rocks of the Fond du Lac Formation tend to be transitional between arkosic and volcaniclastic sedimentary rocks and plot in intermediate positions on the triangular diagram. In addition, they are also slightly enriched in volcanic and sedimentary rock fragments (fig. E4).

Classifying the rocks according to the composition of the rock fragments shows trends similar to those of the petrographic classification (fig. E4). The volcaniclastic sedimentary rocks are mostly volcanic arenite, whereas the arkosic rocks containing metamorphic fragments are classified as phylarenite (only rocks that contain more than 5 percent rock fragments were included). The Nonesuch Shale is an exception. The points plotted on the triangular diagram (fig. E4) reveal the pelitic to aleuritic character of the Nonesuch Shale. The fine-grained volcanic rock fragments in the shale have already been kaolinized, zeolitized, and chloritized, and this accounts for a large proportion of the cement and the chlorite content. In addition, both quartz and iron in these rocks are mainly of volcanic origin.

Metamorphic rock fragments are important components of the arkosic rocks examined. Their texture and composition are such that they are resistant to weathering. Plutonic rocks are generally coarser grained and weather easily, and consequently they contribute more to the mineral fraction of the newly formed rocks.

The characteristic features of the quartz and the composition of the feldspar grains in the upper part of the arkosic sequence suggest that the amount of material derived from older volcanic and volcaniclastic rocks diminished upward. Quartz grains are well rounded in the coarse-grained sandstone and poorly rounded to angular in the finer fractions. Quartz grains commonly show evidence of secondary overgrowths and one or more abrasion rims, indicative of several cycles of sedimentation. Quartz of possible volcanic origin, showing corroded bays, inclusions of devitrified glass and needles of rutile, occurs mostly in the volcaniclastic rocks. They are also characterized by their low quartz content, ranging from 2.6 to 12.4 percent (except sample 16a, which contains 27.3 percent quartz). The quartz content of the arkosic rocks is markedly higher, ranging from 37.8 to 71.3 percent. The quartz content is, to a large extent, determined by the provenance of the rock. The lower quartz content is mainly compensated for by a higher content of pelitic and aleuritic material.

Plagioclase (as much as 5.0 percent) occurs only in the volcaniclastic sedimentary rocks, except for one sample of Jacobsville Sandstone (sample 22a). The feldspar content of the upper Keweenawan sedimentary rocks ranges from 5.7 to 21.3 percent, averaging about $10-15$ percent. Only two samples contain less than 5.0 percent feldspar (table E1). Microcline, orthoclase, and perthite are the predominant feldspars in the clastic rocks.

Opaque iron-rich aggregates of magmatic or metamorphic origin are important components of volcaniclastic sedimentary rocks, whereas clayey and muddy intraclasts are more common in ferruginous arkosic rocks. The elevated amount of metamorphic ferruginous rock fragments in the Jacobsville Sandstone may be derived from nearby ironformation.

Except for the Nonesuch Shale, the amount of phyllosilicates is generally higher in the arkosic rocks. Secondary metasomatic alteration and, to a certain extent, the depositional environment contribute to the enrichment of the Nonesuch Shale in phyllosilicates, especially chlorite. Cement in the majority of samples consists mainly of iron oxides and clay (table E1). Quartz and carbonate are the predominant cement in a few samples. Zeolite is an important cement-forming mineral in the Nonesuch Shale and is as high as 13.2 percent (sample 16a; table E1, under "other cement"). These variations are believed to be controlled primarily by the depositional environment.

The phosphorite and glauconite content of all Precambrian rocks is low (less than 0.5 percent), as opposed to that of the Lower Cambrian rocks studied. The porosity increases with maturity of the rocks and reaches a maximum in quartz arenite of the Hinckley Sandstone and the Devils Island Sandstone.

\section{HEAVY-MINERAL ANALYSIS}

There is a noticeable difference in the heavy-mineral composition of volcaniclastic sedimentary rocks of the Oronto Group as compared to the increasingly more arkosic rocks of the Bayfield Group. The older volcaniclastic sedimentary rocks, such as the Freda Sandstone and the Nonesuch Shale, contain as much as 3 percent (by volume) heavy minerals, most of which are opaque and semiopaque ferroan metamorphic minerals, iron titanium oxides, and some sulfides, as well as a small amount of mostly authigenic epidote. The epidote group of minerals consists of pistacite, normal epidote, and clinozoisite. Small amounts of garnet, zircon, and rutile are present, but tourmaline is absent.

On the basis of studies by Tyler and others (1940), and also reported by Dickas (1986), we know that the ratio of combined tourmaline and zircon to epidote in the Bayfield Group is the reverse of that in the Freda and Nonesuch assemblages. We found the same pattern in our studies (table E2) and used this information as a discriminating factor in correlating subsurface samples with known stratigraphy.

In the younger arkosic rocks of the Bayfield Group, the combined amounts of zircon, tourmaline, garnet, rutile, and 
hornblende, with few exceptions, make up a larger fraction of the heavy-mineral suite than in the more mature and older rocks of the Oronto Group. Elevated amounts of partly authigenic apatite occur in the transitional rocks of the Orienta Sandstone and the Fond du Lac Formation. Inconsistencies in the expected makeup of the heavymineral fraction in some of the rocks may be attributable to differences in the local environment of deposition. The amount of opaque and semi-opaque minerals in the heavymineral fraction varies from 3 to 90 percent, and in most cases exceeds 40 percent.

The heavy-mineral composition of the drill core samples is characterized by generally elevated amounts of zircon and tourmaline (table E3) and low contents of epidote (except for sample LO-6), which is similar to the heavymineral composition of the upper clastic rocks. The apatite content is characteristic of rocks of the Orienta Sandstone and the Fond du Lac Formation.

\section{DISCUSSION}

Until recently, when two deep oil exploration wells were drilled into the buried southern extension of the rift in Iowa and Kansas, most of our knowledge about the history and development of the rift was derived from studies in the outcrop belt in Minnesota, Wisconsin, and Michigan. The 1,281-Ma age of the gabbro (Van Schmus and others, 1990 ) below the sedimentary section in the Eischeid \#1 drill hole in Carroll County, Iowa, is evidence (Van Schmus and others, 1990) that the complete Keweenawan sedimentary sequence was penetrated at that location. Stratigraphic (Witzke, 1990) and petrologic (Ludvigson and others, 1990) studies of the Keweenawan section in the basin west of the Iowa horst, enabled Witzke (1990) to tentatively correlate rocks of the Oronto and Bayfield Groups with those in the Eischeid \#1 well. The gabbro in the Texaco Poersch \#1 drill hole, in Washington County, Kansas, was dated at 1,097.5 Ma (Van Schmus and others, 1990). The important inference is that rifting was initiated at the same time as in the Lake Superior region. Thus, even though the rift in Kansas is physically separated from the rift farther north, stratigraphic correlations may be made between the rocks in Kansas and those in Nebraska, Iowa, and Minnesota.

The initial opening of the rift (graben formation) at about 1,100 Ma was characterized by the eruption of large volumes of mafic volcanic rock and shallow mafic intrusive rocks over a time span of about 100 million years (McSwiggen and others, 1987; Behrendt and others, 1988; Chandler and others, 1989). After cessation of the main phase of volcanic activity, during which time the area apparently remained above sea level, the central graben began to fill with coarse volcaniclastic rocks and coarse interflow conglomerate. This sequence was overlain by rocks of the Copper Harbor Conglomerate, representing a prograding alluvial-fan complex (Daniels, 1982). The overlying Nonesuch Shale was deposited in a riftflanking lacustrine environment, probably caused by disruption and damming of existing drainages (Daniels, 1982).

The clastic sedimentary succession overlying the volcanic rocks was divided into the Oronto (lower) and the Bayfield (upper) Groups (Thwaites, 1912), each of which exhibits distinct characteristics (fig. E1). We refer to the older Oronto Group as a volcaniclastic sequence because the rocks contain abundant debris derived from the underlying volcanics. In addition, Dickas (1986) mentioned an upward and distal decrease in grain size. Elmore and Daniels (1980) viewed the depositional environment of the Oronto Group as a transgressive-regressive alluvial-fan, lacustrine, and fluvial system, which Morey and Ojakangas (1982) considered characteristic of an extensional regime.

During the evolution of the rift, contributions from rocks exposed in the nearby highlands east and west of the graben increased (Merk and Jersa, 1982). The rocks of the younger Bayfield Group are compositionally more mature. The heavy-mineral suite of the group as a whole is different from that of the underlying Oronto Group. Individual formations such as the Orienta Sandstone and the Fond du Lac Formation contain large amounts (as much as 12.1 percent) of authigenic apatite. Plagioclase is a less common mineral constituent; orthoclase and microcline feldspar instead became prominent. Metamorphic fragments predominate over volcanic fragments.

The rift is characterized by an axial horst flanked by clastic-filled basins (Anderson, 1990; Dickas, 1986). Axial basins are known to occur in Minnesota, Iowa, and Nebraska. Anderson (1990) mentioned that late-fill rift sediments are locally preserved in the axial basins (Anderson, 1990).

Geologic studies by Morey and Ojakangas (1982) and gravity and magnetic modeling by McSwiggen and others (1987) suggest that some of the axial basins contain older and denser sedimentary rocks of the Oronto Group, which are as much as several miles thick. If this is true, then the central horst must have developed after deposition of the Solor Church Formation-Oronto Group, but not necessarily before deposition of the Bayfield Group.

Rift-related faults were periodically reactivated throughout geologic time (Berendsen and others, 1990), resulting in extensive erosion from topographic highs and preservation of the sedimentary section in downdropped blocks along the axial trace of the rift. High-angle normal and reverse faults and overthrusting juxtaposed rocks of different lithologies and ages. Woelk and Hinze (1991) interpreted seismic data to show a major reverse fault in 
the stratigraphic succession in the Texaco Poersch \#1 deep drill hole into the Precambrian in Washington County, Kansas (Berendsen and others, 1988). In this drill hole a 4,600-ft-thick unit of primarily basalt and gabbro $(1,097.5$ Ma) overlies a 3,900-ft-thick package of presumably younger, primarily arkosic rocks.

\section{ACKNOWLEDGMENTS}

This study was made possible through the cooperation and support of the USGS through the Midcontinent Strategic and Critical Minerals Project. We also acknowledge the cooperation of geological survey personnel in the states of Minnesota, Wisconsin, and Michigan. They were very helpful in providing us access to core and leading us to outcrops.

\section{REFERENCES CITED}

Adler, F.J., coordinator, 1987, Correlation of stratigraphic units in North America (COSUNA) Project-Mid-continent Region: Tulsa, Okla., American Association of Petroleum Geologists.

Anderson, R.R., 1990, Review of the Precambrian geological history of the central United States and the midcontinent rift system, in Anderson, R.R., ed., The Amoco M.G. Eischeid \#1 deep petroleum test, Carroll County, Iowa-Preliminary Investigations: Iowa Department of Natural Resources Special Report Series No. 2, p. 1-25.

Baars, D.L., editor, in press, Lexicon of stratigraphic nomenclature for Kansas: Kansas Geological Survey Bulletin 231.

Barghoorn, E.S., Meinschein, W.E., and Schopf, J.W., 1965, Paleobiology of Precambrian shale: Science, v. 148, p. 461-472.

Behrendt, J.C., Green, A.G., Cannon, W.F., Hutchinson, D.R., Lee, M., Milkereit, B., Agena, W.F., and Spencer, C., 1988, Crustal structure of the Midcontinent rift system-Results from GLIMPCE deep seismic reflection profiles: Geology, v. 16, p. 81-85.

Berendsen, Pieter, Borcherding, R.M., Doveton, J., Newell, K.D., Steeples, D., and Watney, W.L., 1988, Texaco Poersch \# 1, Washington County, Kansas-Preliminary geologic report of the pre-Phanerozoic rocks: Kansas Geological Survey Open-File Report 88-22, 116 p.

Berendsen, Pieter, Newell, K.D., and Blair, K.P., 1990, Structural aspects of the Mid-Continent rift system in Kansas, in Transaction volume of the 1989 AAPG Mid-Continent Section Meeting: Oklahoma City, Okla., Oklahoma City Geological Society, $26 \mathrm{p}$.

Chandler, V.W., 1983, Correlation of magnetic anomalies in eastcentral Minnesota and northwestern WisconsinConstraints on magnitude and direction of Keweenawan rifting: Geology, v. 11, p. 174-176.

Chandler, V.W., McSwiggen, P.L., Morey, G.B., Hinze, W. J., and Anderson, R.R., 1989, Interpretation of seismic reflection, gravity, and magnetic data across Middle Proterozoic MidContinent rift system, northwestern Wisconsin, eastern
Minnesota, and central Iowa: American Association of Petroleum Geologists Bulletin, v. 73, p. 261-275.

Chase, C.G., and Gilmer, T.H., 1973, Precambrian plate tectonics-The Midcontinent gravity high: Earth and Planetary Science Letters, v. 21, p. 70-78.

Chumakov, N.M., and Elston, D.P., 1989, The paradox of Late Proterozoic glaciations at low latitudes: Episodes, v. 12, p. 115-120.

Crittendon, M.D., Christie-Blick, N., and Link, P.K., 1983, Evidence for two pulses of glaciation during the Late Proterozoic in northern Utah and southeastern Idaho: Geological Society of America Bulletin, v. 94, p. 437-450.

Daniels, Jr., P.A., 1982, Upper Precambrian sedimentary rocks, Oronto Group, Michigan-Wisconsin, in Wold, R.J., and Hinze, W.J., eds., Geology and tectonics of the Lake Superior Basin: Geological Society of America Memoir 156, p. 107-133.

Dickas, A.B., 1984, Midcontinent rift system-Precambrian hydrocarbon target: Oil and Gas Journal, v. 82 (October 15), p. 151-159.

1986, Comparative Precambrian stratigraphy and structure along the Mid-Continent rift: American Association of Petroleum Geologists Bulletin, v. 70, p. 225-238.

Donaldson, J.A., 1989, Quartz arenites as evidence of episodic crustal stability during the Precambrian-Examples from Canadian Shield: Washington, D.C., 28th International Geological Congress, 1989, Abstracts, v. 1, p. 405.

Eglinton, Geoffrey, Scott, P.M., Belsky, T., Burlingame, A.L., and Calvin, M., 1964, Hydrocarbons of biological origin from a one-billion-year-old sediment: Science, v. 145, p. 263-264.

Ehrlich, Robert, and Vogel, T.A., 1971, Depositional and diagenetic model for the lower Nonesuch Shale based on lithologic variation: White Pine, Mich., White Pine Copper Company unpublished technical report, $121 \mathrm{p}$.

Elmore, R.D., and Daniels P.A., 1980, Depositional system model for upper Keweenawan Oronto Group sediments, Northern Peninsula, Michigan [abs.]: EOS, v. 61, p. 1195.

Ensign, C.O., White, W.S., Wright, J.C., Patrick, J.L., Leone, R.J., Hathaway, D.J., Trammell, J.W., Fritts, J.J., and Wright, T.L., 1968, Copper deposits in the Nonesuch Shale, White Pine, Michigan, in Ridge, J.D., ed., Ore deposits of the United States, 1933-1967 (Graton-Sales Volume): New York, American Institute of Mining, Metallurgical, and Petroleum Engineers, Inc., p. 460-488.

Hamblin, W.K., 1958, Cambrian sandstones of northern Michigan: Michigan Department of Conservation, Geological Survey Division Publication 51, 149 p.

Hubbard, H.A., 1975, Geology of Porcupine Mountains in Carp River and White Pine quadrangles, Michigan: U. S. Geological Survey Journal of Research, v. 3, p. 519-528.

Jost, Manfred, 1968, The White Pine copper districtMineralogical investigation and genetic interpretation: Mainz, Federal Republic of Germany, Johannes Guttenberg University, Ph.D. dissertation, 78 p.

Kalliokoski, Joseph, 1982, Jacobsville Sandstone, in Wold, R.J., and Hinze, W.J., eds., Geology and tectonics of the Lake Superior Basin: Geological Society of America Memoir 156, p. 147-155.

Kelly, W.C., and Nishioka, G.K., 1985, Precambrian oil inclusions in late veins and the role of hydrocarbons in copper mineralization at White Pine, Michigan: Geology, v. 13, p. 334-337. 
Krynine, P.D., 1948, The megascopic study and field classification of sedimentary rocks: Journal of Geology, v. 56, p. 130-165.

Lane, A.C., and Seaman, A.E., 1907, Notes on the geological section of Michigan; Part 1, pre-Ordovician: Journal of Geology, v. 15, p. 680-695.

Lidiak, E.G., 1972, Precambrian rocks in the subsurface of Nebraska: Nebraska Geological Survey Bulletin 26, $41 \mathrm{p}$.

Ludvigson, G.A., McKay, R.M, and Anderson, R.R., 1990, General stratigraphy of the Phanerozoic and Keweenawan sequence, M.G. Eischeid \#1 drill hole, Carroll Co., Iowa, in Anderson, R.R., ed., The Amoco M.G. Eischeid \#1 deep petroleum test, Carroll County, Iowa: Iowa Department of Natural Resources, Geological Survey Bureau Special Report Series No. 2, p. 39-58.

Lugn, A.L., 1934, Pre-Pennsylvanian stratigraphy of Nebraska: American Association of Petroleum Geologists Bulletin, v. 18, p. 1597-1631.

McSwiggen, P.L., Morey, G.B., and Chandler V.W., 1987, New model of the Midcontinent Rift in eastern Minnesota and western Wisconsin: Tectonics, v. 6, p. 677-685.

Merk, G.P., and Jirsa, M.A., 1982, Provenance and tectonic significance of the Keweenawan interflow sedimentary rocks, in Wold, R.J., and Hinze, W.J., eds., Geology and tectonics of the lake Superior Basin: Geological Society of America Memoir 156, p. 97-105.

Miller, J.M.G., 1989, Glacial and glacilacustrine sedimentation in a rift setting-Upper Proterozoic Mount Rogers Formation, S.W. Virginia, U.S.A.: Washington, D.C., 28th International Geological Congress, 1989, Abstracts, v. 2, p. 436-437.

Mooney, H.M., Craddock, C., Farnham, P.R., Johnson, S.H., and Volz, G.A., 1970, Refraction seismic investigation of the northern Midcontinent gravity high: Journal of Geophysical Research, v. 75, p. 5056-5086.

Morey, G.B., 1967, Stratigraphy and petrology of the type Fond du Lac Formation, Duluth, Minnesota: Minnesota Geological Survey Report of Investigations 7, 25 p.

1972, Petrology of Keweenawan sandstones in the subsurface of southeastern Minnesota, in Sims, P.K., and Morey, G.B., eds., Geology of Minnesota-A centennial volume: Minnesota Geological Survey, p. 436-449.

1977, Revised Keweenawan subsurface stratigraphy, southeastern Minnesota: Minnesota Geological Survey Report of Investigations $16,67 \mathrm{p}$

Morey, G.B., and Green, J.C., 1982, Status of the Keweenawan as a stratigraphic unit in the Lake Superior region, in Wold, R.J., and Hinze, W.J., eds., Geology and tectonics of the Lake Superior Basin: Geological Society of America Memoir 156, p. 15-26.

Morey, G.B., and Ojakangas, R.W., 1982, Keweenawan sedimentary rocks of eastern Minnesota and northwestern Wisconsin, in Wold, R.J., and Hinze, W.J., eds., Geology and tectonics of the Lake Superior Basin: Geological Society of America Memoir 156, p. 135-146.

Myers, W.D., 1971, The sedimentology and tectonic significance of the Bayfield Group (upper Keweenawan?) Wisconsin and Minnesota: Madison, University of Wisconsin, Ph.D. dissertation, $269 \mathrm{p}$.

Pettijohn, F.J., Potter, P.E., and Siever, R., 1972, Sand and sandstone: Berlin-Heidelberg, Springer-Verlag, $618 \mathrm{p}$.

Roy, J.L., and Robertson, W.A., 1978, Paleomagnetism of the Jacobsville Formation and the apparent polar path for the interval -110 to -670 m.y. for North America: Journal of Geophysical Research, v. 83, p. 1289-1304.

Serpa, Laura, Setzer, H., Farmer, L., Brown, J., Oliver, S., Kaufman, S., and Sharp, J., 1984, Structure of southern Keweenawan rift from COCORP surveys across the Midcontinent geophysical anomaly in northeastern Kansas: Tectonics, v. 3, p. 367-384.

Thiel, E.C., 1956, Correlation of gravity anomalies with the Keweenawan geology of Wisconsin and Minnesota: Geological Society of America Bulletin, v. 67, p. 1079-1100.

Thwaites, F.T., 1912, Sandstones of the Wisconsin coast of lake Superior: Wisconsin Geological and Natural History Bulletin $25,17 \mathrm{p}$.

Tryhorn, A.D., and Ojakangas, R.W., 1972, Sedimentation and petrology of the upper Precambrian Hinckley Sandstone of east-central Minnesota, in Sims, P.K., and Morey, G.B., eds., Geology of Minnesota-A centennial volume: Minnesota Geological Survey, p. 431-435.

Tyler, S.A., Marsden, R.W., Grout, F.F., and Thiel, G.A., 1940, Studies of the Lake Superior Pre-Cambrian by accessorymineral methods: Geological Society of America Bulletin, v. 51, p. 1429-1538.

Van Schmus, W.R., and Bickford, M.E., 1989, Early Proterozoic crustal evolution in the central United States: Washington, D.C., 28th International Geological Congress, 1989, Abstracts, v. 3, p. 282.

Van Schmus, W.R., Green, J.C., and Halls, H.C., 1982, Geochronology of Keweenawan rocks of the Lake Superior regionA summary, in Wold, R.J., and Hinze, W.J., eds., Geology and tectonics of the Lake Superior Basin: Geological Society of America Memoir 156, p. 165-171.

Van Schmus, W.R., Martin, M.W., Sprowl, D.R., Geissman, J., and Berendsen, P., 1990, Age, Nd and Pb isotopic composition, and magnetic polarity for subsurface samples of the $1100 \mathrm{Ma}$ Midcontinent rift: Geological Society of America Abstracts with Programs, v. 22, no. 7, p. A174.

Van Schmus, W.R., Wallin, E.T., and Shearer, C.K., 1990, Age relationships for gabbro from the Amoco M.G. Eischeid \#1 well, in Anderson, R.R., ed., The Amoco M.G. Eischeid \#1 deep petroleum test, Carroll County, Iowa, Preliminary Investigations: Iowa Department of Natural Resources, Geological Survey Bureau Special Report Series, No. 2, p. 67-76.

White, W.S., 1972, The base of the upper Keweenawan, Michigan and Wisconsin: U. S. Geological Survey Bulletin 1354-F, p. 1-23.

Witzke, B.J., 1990, General stratigraphy of the Phanerozoic and Keweenawan sequence, M.G. Eischeid \#1 drillhole, Carroll Co., Iowa, in Anderson, R.R., ed., The Amoco M.G. Eischeid \#1 deep petroleum test, Carroll County, Iowa, Preliminary Investigations: Iowa Department of Natural Resources, Geological Survey Bureau Special Report Series, No. 2, p. 39-58.

Woelk, T.S., 1989, An integrated geophysical study of the Midcontinent Rift System in northeastern Kansas: Lafayette, Ind., Purdue University, M.Sc. thesis, 75 p.

Woelk, T.S., and Hinze, W.J., 1991, Model of the midcontinent rift system in northeastern Kansas: Geology, v. 19 (March 1991), p. 277-280.

Wold, R.J., and Hinze, W.J., eds., 1982, Geology and tectonics of the Lake Superior basin: Geological Society of America Memoir 156, 280 p. 


\section{SELECTED SERIES OF U.S. GEOLOGICAL SURVEY PUBLICATIONS}

\section{Periodicals}

Earthquakes \& Volcanoes (issued bimonthly). Preliminary Determination of Epicenters (issued monthly).

\section{Technical Books and Reports}

ProfessionaI Papers are mainly comprehensive scientific reports of wide and lasting interest and importance to professional scientists and engineers. Included are reports on the results of resource studies and of topographic, hydrologic, and geologic investigations. They also include collections of related papers addressing different aspects of a single scientific topic.

Bulletins contain significant data and interpretations that are of lasting scientific interest but are generally more limited in scope or geographic coverage than Professional Papers. They include the results of resource studies and of geologic and topographic investigations; as well as collections of short papers related to a specific topic.

Water-Supply Papers are comprehensive reports that present significant interpretive results of hydrologic investigations of wide interest to professional geologists, hydrologists, and engineers. The series covers investigations in all phases of hydrology, including hydrology, availability of water, quality of water, and use of water.

Circulars present administrative information or important scientific information of wide popular interest in a format designed for distribution at no cost to the public. Information is usually of short-term interest.

Water-Resources Investigations Reports are papers of an interpretive nature made available to the public outside the formal USGS publications series. Copies are reproduced on request unlike formal USGS publications, and they are also available for public inspection at depositories indicated in USGS catalogs.

Open-File Reports include unpublished manuscript reports, maps, and other material that are made available for public consultation at depositories. They are a nonpermanent form of publication that maybe cited in other publications as sources of information.

\section{Maps}

Geologic Quadrangle Maps are multicolor geologic maps on topographic bases in $71 / 2$ - or 15 -minute quadrangle formats (scales mainly $1: 24,000$ or $1: 62,500$ ) showing bedrock, surficial, or engineering geology. Maps generally include brief texts; some maps include structure and columnar sections only.

Geophysical Investigations Maps are on topographic or planimetric bases at various scales, they show results of surveys using geophysical techniques, such as gravity, magnetic, seismic, or radioactivity, which reflect subsurface structures that are of economic or geologic significance. Many maps include correlations with the geology.

Miscellaneous Investigations Series Maps are on planimetric or topographic bases of regular and irregular areas at various scales; they present a wide variety of format and subject matter. The series also includes 7 1/2-minute quadrangle photogeologic maps on planimetric bases which show geology as interpreted from aerial photographs. The series also includes maps of Mars and the Moon.
Coal Investigations Maps are geologic maps on topographic or planimetric bases at various scales showing bedrock or surficial geology, stratigraphy, and structural relations in certain coal-resource areas.

Oil and Gas Investigations Charts show stratigraphic information for certain oil and gas fields and other areas having petroleum potential.

Miscellaneous Field Studies Maps are multicolor or black-andwhite maps on topographic or planimetric bases on quadrangle or irregular areas at various scales. Pre-1971 maps show bedrock geology in relation to specific mining or mineral-deposit problems; post-1971 maps are primarily black-and-white maps on various subjects such as environmental studies or wilderness mineral investigations.

Hydrologic Investigations A tlases are multicolored or black-andwhite maps on topographic or planimetric bases presenting a wide range of geohydrologic data of both regular and irregular areas; the principal scale is $1: 24,000$, and regional studies are at $1: 250,000$ scale or smaller.

\section{Catalogs}

Permanent catalogs, as well as some others, giving comprehensive listings of U.S. Geological Survey publications are available under the conditions indicated below from USGS Map Distribution, Box 25286, Building 810, Denver Federal Center, Denver, CO 80225. (See latest Price and Availability List.)

"Publications of the Geological Survey, 1879-1961" may be purchased by mail and over the counter in paperback book form and as a set microfiche.

"Publications of the Geological Survey, 1962-1970" may be purchased by mail and over the counter in paperback book form and as a set of microfiche.

"Publications of the U.S. Geological Survey, 1971-1981" may be purchased by mail and over the counter in paperback book form (two volumes, publications listing and index) and as a set of microfiche.

Supplements for $1982,1983,1984,1985,1986$, and for subsequent years since the last permanent catalog may be purchased by mail and over the counter in paperback book form.

State catalogs, "List of U.S. Geological Survey Geologic and Water-Supply Reports and Maps For (State)," may be purchased by mail and over the counter in paperback booklet form only.

"Price and Availability List of U.S. Geological Survey Publications," issued annually, is available free of charge in paperback booklet form only.

Selected copies of a monthly catalog "New Publications of the U.S. Geological Survey" is available free of charge by mail or may be obtained over the counter in paperback booklet form only. Those wishing a free subscription to the monthly catalog "New Publications of the U.S. Geological Survey" should write to the U.S. Geological Survey, $582 \mathrm{Na}$ tional Center, Reston, VA 22092.

Note--Prices of Government publications listed in older catalogs, announcements, and publications may be incorrect. Therefore, the prices charged may differ from the prices in catalogs, announcements, and publications. 
